\title{
Vitamin D Effects on Cell Differentiation and Stemness in Cancer
}

\author{
Asunción Fernández-Barral $\mathbb{D}^{\mathbb{D}}$, Pilar Bustamante-Madrid $\mathbb{D}$, Gemma Ferrer-Mayorga,

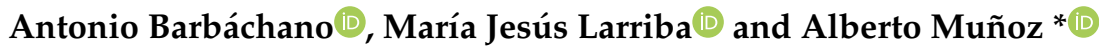

Instituto de Investigaciones Biomédicas "Alberto Sols", Consejo Superior de Investigaciones Científicas, Universidad Autónoma de Madrid, Instituto de Investigación Hospital Universitario La Paz, and CIBERONC, Arturo Duperier 4, 28029 Madrid, Spain; afbarral@iib.uam.es (A.F.-B.); pbustamante@iib.uam.es (P.B.-M.); gferrer@iib.uam.es (G.F.-M.); abarbachano@iib.uam.es (A.B.); mjlarriba@iib.uam.es (M.J.L.)

* Correspondence: amunoz@iib.uam.es; Tel.: +34-915-854-451

Received: 31 July 2020; Accepted: 22 August 2020; Published: 25 August 2020

\begin{abstract}
Vitamin $\mathrm{D}_{3}$ is the precursor of $1 \alpha, 25$-dihydroxyvitamin $\mathrm{D}_{3}\left(1,25(\mathrm{OH})_{2} \mathrm{D}_{3}\right)$, a pleiotropic hormone that is a major regulator of the human genome. $1,25(\mathrm{OH})_{2} \mathrm{D}_{3}$ modulates the phenotype and physiology of many cell types by controlling the expression of hundreds of genes in a tissue- and cell-specific fashion. Vitamin D deficiency is common among cancer patients and numerous studies have reported that $1,25(\mathrm{OH})_{2} \mathrm{D}_{3}$ promotes the differentiation of a wide panel of cultured carcinoma cells, frequently associated with a reduction in cell proliferation and survival. A major mechanism of this action is inhibition of the epithelial-mesenchymal transition, which in turn is largely based on antagonism of the Wnt $/ \beta$-catenin, TGF- $\beta$ and EGF signaling pathways. In addition, $1,25(\mathrm{OH})_{2} \mathrm{D}_{3}$ controls the gene expression profile and phenotype of cancer-associated fibroblasts (CAFs), which are important players in the tumorigenic process. Moreover, recent data suggest a regulatory role of $1,25(\mathrm{OH})_{2} \mathrm{D}_{3}$ in the biology of normal and cancer stem cells (CSCs). Here, we revise the current knowledge of the molecular and genetic basis of the regulation by $1,25(\mathrm{OH})_{2} \mathrm{D}_{3}$ of the differentiation and stemness of human carcinoma cells, CAFs and CSCs. These effects support a homeostatic non-cytotoxic anticancer action of $1,25(\mathrm{OH})_{2} \mathrm{D}_{3}$ based on reprogramming of the phenotype of several cell types.
\end{abstract}

Keywords: vitamin D; cell differentiation; stemness; cancer; carcinoma cells; cancer-associated fibroblasts; cancer stem cells; organoids; epithelial-mesenchymal transition; Wnt $/ \beta$-catenin

\section{Introduction}

Vitamin $\mathrm{D}_{3}$, or cholecalciferol, is a secosteroid molecule synthesized in the human skin by the action of solar UV-B light on 7-dehydrocholesterol. A second, limited source (around $10 \%$ ) of vitamin $\mathrm{D}_{3}$ in the human organism is the diet, particularly fatty fish such as salmon, herring and sardines. Cholecalciferol is biologically inert. It enters the bloodstream and is hydroxylated at position C-25 in the liver by cytochrome CYP2R1 to render 25-hydroxyvitamin $\mathrm{D}_{3}\left(25(\mathrm{OH}) \mathrm{D}_{3}\right.$, calcidiol or calcifediol). $25(\mathrm{OH}) \mathrm{D}_{3}$ is then subjected to another hydroxylation at position C-1 by cytochrome CYP27B1, mainly by kidney tubular cells and also by several types of epithelial and immune cells, to form $1 \alpha, 25$-dihydroxyvitamin $\mathrm{D}_{3}\left(1,25(\mathrm{OH})_{2} \mathrm{D}_{3}\right.$, calcitriol) [1-3]. Both $25(\mathrm{OH}) \mathrm{D}_{3}$ and $1,25(\mathrm{OH})_{2} \mathrm{D}_{3}$ bind to the vitamin $\mathrm{D}$ receptor (VDR) protein, one of the 48 members of the ligand-activated transcription factor superfamily of nuclear hormone receptors. Although some controversy exists, $1,25(\mathrm{OH})_{2} \mathrm{D}_{3}$ appears to bind VDR with higher affinity and efficacy in terms of gene regulation than $25(\mathrm{OH}) \mathrm{D}_{3}$. Ligand binding promotes the formation of heterodimers between VDR and RXR, the receptor for 9-cis-retinoic acid, and the binding of these VDR-RXR heterodimers to DNA [1-3]. 
Chromatin immunoprecipitation sequencing assays have revealed the presence of around ten thousand VDR DNA binding sites in the human genome [4]. They are distributed throughout the whole genome. A subset is located close to the transcription initiation site of the genes that are directly regulated by $1,25(\mathrm{OH})_{2} \mathrm{D}_{3}$, but in many cases they are located upstream of the transcription initiation site or in introns, in the coding sequence, or downstream target genes. In line with the high number of VDR DNA binding sites, $1,25(\mathrm{OH})_{2} \mathrm{D}_{3}$ regulates the expression of hundreds of genes that vary between tissues, cell types and context $[5,6]$. Accordingly, $1,25(\mathrm{OH})_{2} \mathrm{D}_{3}$ displays a whole set of functions in the organism. The long-term knowledge of the association of vitamin $\mathrm{D}$ deficiency with rickets in children and osteomalacia in adults led to the consideration of calcium and phosphate metabolism and bone biology as the main roles of vitamin D in humans. However, during evolution, VDR was probably involved first in energy metabolism and defense against infections, and $1,25(\mathrm{OH})_{2} \mathrm{D}_{3}$ is today considered an important multifaceted regulator of the immune system [7].

$1,25(\mathrm{OH})_{2} \mathrm{D}_{3}$ was initially linked to cancer in 1981, when the groups of D. Feldman and T. Suda reported its effect of inhibiting the proliferation of cultured human melanoma cells and inducing the differentiation of mouse myeloid leukemic cells, respectively [8,9]. During the last four decades, many studies have confirmed that $1,25(\mathrm{OH})_{2} \mathrm{D}_{3}$ attenuates the proliferation rate of many types of cancer cells, usually in association with a differentiation-inducing effect. In recent years, it has been shown that $1,25(\mathrm{OH})_{2} \mathrm{D}_{3}$ regulates the gene expression profile and phenotype of stromal fibroblasts present in the tumor microenvironment. Moreover, several studies have indicated that $1,25(\mathrm{OH})_{2} \mathrm{D}_{3}$ modulates cell stemness in a few cancer systems. Here, we review this set of actions, positing $1,25(\mathrm{OH})_{2} \mathrm{D}_{3}$ as a crucial regulator of homeostasis in the organism and as a candidate for non-cytotoxic anticancer therapies based on the regulation of cancer cell differentiation and stemness.

\section{Effects of $1,25(\mathrm{OH})_{2} \mathrm{D}_{3}$ on Cancer Cell Differentiation}

\subsection{Carcinomas: The Epithelial-Mesenchymal Transition}

Carcinomas are the most frequent (around 90\%) type of solid cancer. They arise from epithelial cells that, in the early steps of the tumorigenic process, lose control of their proliferation and two features of their differentiated phenotype: (i) apical-basal polarity, which is the differential distribution of proteins and lipids at distinct cell surface areas that in this way are functionally diverse, and (ii) adhesiveness, which is the ability to bind strongly to neighboring epithelial cells and to the extracellular matrix (ECM) by means of a series of specialized cell adhesion structures. The loss of epithelial differentiation results from the acquisition of a cellular program called epithelial-mesenchymal transition (EMT). EMT involves drastic changes in the pattern of gene expression, triggered by a group of transcription factors (EMT-TFs: mainly SNAIL1, SNAIL2, ZEB1, ZEB2 and TWIST1) that cause repression of the epithelial phenotype and the induction of a mesenchymal state $[10,11]$. Thus, diverse epithelial cell surface proteins responsible for adhesiveness-including components of adherens junctions such as E-cadherin (considered a hallmark of the adhesive differentiated epithelial phenotype), tight junctions such as claudins and occludin, and desmosomes, as well as cytoskeletal components (cytokeratins), some ECM-binding integrins and polarity regulators (such as the Crumbs, Par and Scribble complexes) - are replaced by others typical of motile fibroblastic cells. These include $\mathrm{N}$-cadherin, a distinct panel of integrins, vimentin and ECM-degrading metalloproteases (MMP). As a result, epithelial cells remodel their cytoskeletons, lose cell-cell and cell-ECM adhesion, change to a front-back polarity and acquire a fibroblastic-like phenotype with motility and basal membrane invasion capacities [11,12]. EMT provides tumor cells with other features of malignancy, such as stemness and diminished apoptosis, which causes resistance to cytotoxic chemo- and radiotherapies and to immunotherapy [11].

Thus, the appearance of a carcinoma involves an initial increased proliferation capacity and also the loss of the differentiated phenotype by epithelial cells that is mostly associated with the EMT program. The increased proliferation capacity gives rise to a mass of initially benign tumor cells growing at their original tissue location, whereas the loss of the differentiated phenotype gives these 
cells the ability to migrate (the first requirement for cancer dissemination and metastasis) and a higher survival capacity. The EMT process is activated by a variety of agents and signals that induce or activate the EMT-TFs such as transforming growth factor (TGF)- $\beta$, Wnt, Notch and ligands of several receptors with tyrosine kinase activity and cytokine receptors. These signals usually act cooperatively and in many cases are produced by stromal cells of the tumor microenvironment [11]. EMT is a reversible and usually a partial phenomenon. It does not affect all cells in a tumor and does not completely abrogate cell polarity and adhesiveness; thus, it generates intratumoral phenotypic heterogeneity. Later during tumorigenesis, EMT is reversed by the opposite process of mesenchymal-epithelial transition (MET). By restoring cell aggregation and binding to ECM, MET probably facilitates the survival of tumor cells during circulation in the bloodstream and the initial colonization of metastatic niches $[10,11]$.

\subsection{Effects of $1,25(\mathrm{OH})_{2} D_{3}$ on the Differentiation of Carcinoma Cells}

Many studies on the effects of $1,25(\mathrm{OH})_{2} \mathrm{D}_{3}$ on carcinoma cells have been performed in colon and breast cancer due to their high incidence and mortality and due to abundant reports pointing to these two neoplasias as those that are most commonly associated with vitamin $\mathrm{D}$ deficiency [13]. As in most cancer cell types, $1,25(\mathrm{OH})_{2} \mathrm{D}_{3}$ reduces proliferation at the cell cycle $\mathrm{G}_{0}-\mathrm{G}_{1}$ transition via the inhibition of retinoblastoma protein phosphorylation by cyclin/cyclin-dependent kinase (CDK) complexes, in part through the induction of CDK inhibitors and the repression of the c-MYC gene [1-3]. Usually, the inhibition of proliferation is accompanied by a reduction in cell survival due to sensitization to apoptotic stimuli, and both effects are linked to the induction of cell differentiation.

\subsubsection{Colon Cancer}

\section{$1,25(\mathrm{OH})_{2} \mathrm{D}_{3}$ Induces Epithelial Differentiation and Inhibits EMT}

In line with its physiological role in the intestine, promoting the absorption of calcium and phosphate, the intestinal epithelium barrier function and xenobiotic metabolism, $1,25(\mathrm{OH})_{2} \mathrm{D}_{3}$ induces the differentiation of normal colon epithelial cells through the upregulation of many epithelial enzymes and markers and through maintaining the morphology typical of the epithelial differentiated phenotype $[14,15]$. Concordantly, in colon carcinoma cells $1,25(\mathrm{OH})_{2} \mathrm{D}_{3}$ induces a change in morphology that increases cell-cell adhesion and cell flattening (Figure 1a), which is paralleled by a decrease in proliferation. This effect is variably profound and directly related to the level of expression of VDR $[16,17]$. Immunofluorescence and global gene expression analyses showed that $1,25(\mathrm{OH})_{2} \mathrm{D}_{3}$ upregulates an array of intercellular adhesion molecules, including E-cadherin (Figure 1a), occludin, claudin-2 and -12, and zonula occludens/tight junction protein- 1 and $-2[16,18] .1,25(\mathrm{OH})_{2} \mathrm{D}_{3}$ induces and/or redistributes several cytokeratins, F-actin, vinculin, plectin, filamin A and paxillin, which modulate the actin cytoskeleton and the intermediate filament network, changing stress fibers and the ECM binding structures (focal adhesion contacts and hemidesmosomes) $[16,17]$. Thus, by controlling a large set of genes and proteins, $1,25(\mathrm{OH})_{2} \mathrm{D}_{3}$ increases cell-cell and cell-ECM adhesion (Figure 2). $1,25(\mathrm{OH})_{2} \mathrm{D}_{3}$ also induces expression of the calcium sensing receptor (CASR) that regulates calcium homeostasis and the differentiation of colon normal epithelium and carcinoma cells [19-23]. Curiously, $1,25(\mathrm{OH})_{2} \mathrm{D}_{3}$ has distinct effects on inhibitors of differentiation (ID)- 1 and -2 , two members of the ID family of proteins that control the differentiation, proliferation, migration and invasion of multiple cell types. Thus, in SW480-ADH human colon carcinoma cells, $1,25(\mathrm{OH})_{2} \mathrm{D}_{3}$ induces ID- 1 but decreases ID-2 expression [24].

An in-depth study revealed that the induction of the E-cadherin protein by $1,25(\mathrm{OH})_{2} \mathrm{D}_{3}$ depends on the activation of an extranuclear signaling pathway involving the entry of $\mathrm{Ca}^{2+}$ from the external medium into the cytosol and the cascade activation of the RhoA small GTPase and the kinases ROCK, p38MAPK and MSK1. The activation of this pathway potentiates transcription of the CDH1/E-cadherin gene promoted by ligand-activated VDR, leading to the accumulation of the E-cadherin protein at the adherens junctions, along with the enhancement of cell-cell adhesion [17]. In a separate study, 
the kinase PIP4K2B has been reported to be necessary for E-cadherin induction by $1,25(\mathrm{OH})_{2} \mathrm{D}_{3}$ in colon carcinoma cells [25].

a
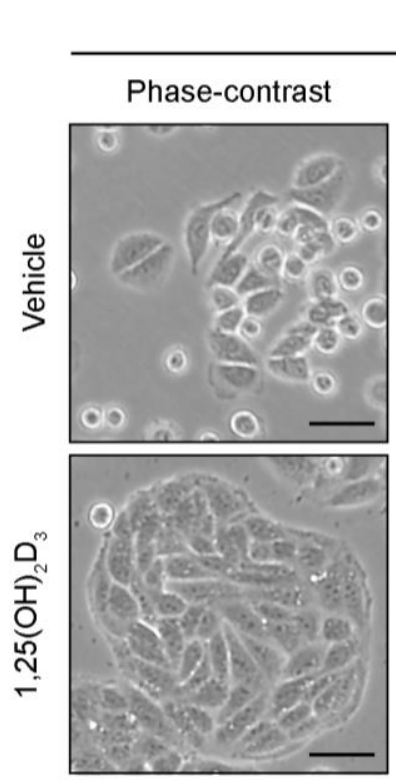

SW480-ADH
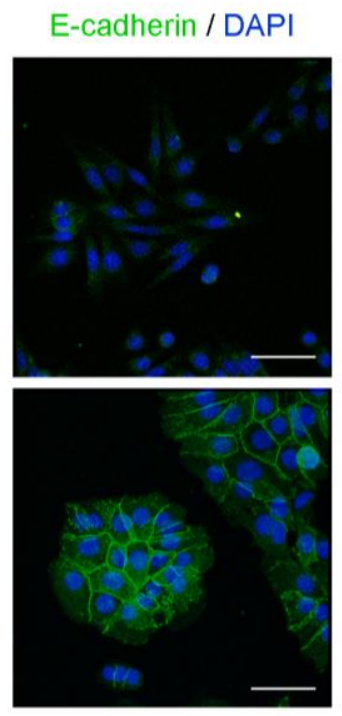

Human tumor organoids b

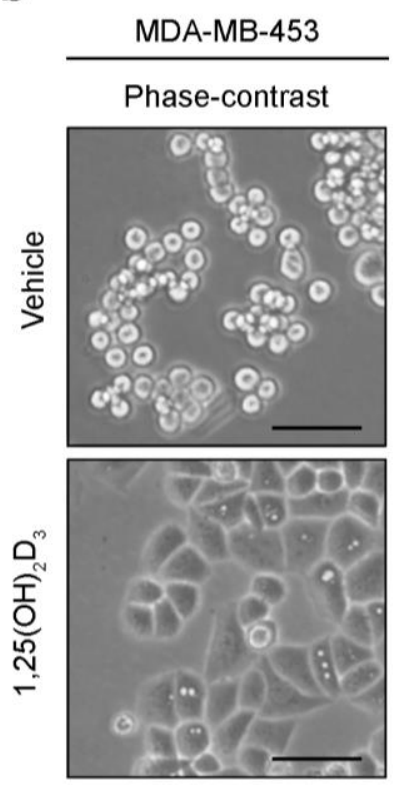

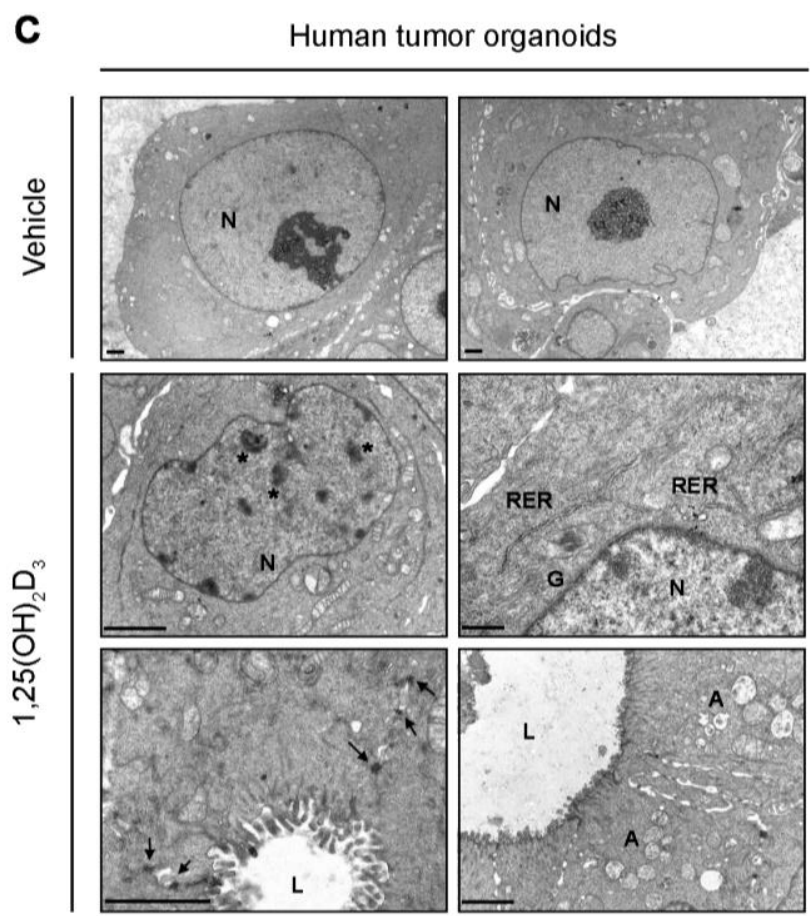

Figure 1. Effects of $1,25(\mathrm{OH})_{2} \mathrm{D}_{3}$ on the phenotype of human colon and breast carcinoma cells and colon tumor organoids. (a) Phase-contrast and immunofluorescence confocal microscopy images of

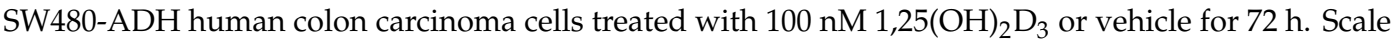
bars, $50 \mu \mathrm{m}$. (b) Phase-contrast microscopy images of MDA-MB-453 human breast carcinoma cells treated with $100 \mathrm{nM} 1,25(\mathrm{OH})_{2} \mathrm{D}_{3}$ or vehicle for $72 \mathrm{~h}$. Scale bars, $50 \mu \mathrm{m}$. (c) Electron microscopy images

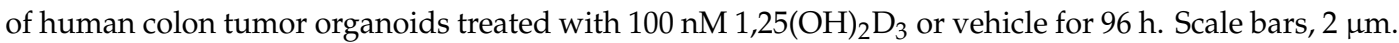
A, autophagic vacuoles; G, Golgi complexes; L, lumen; N, nucleus; RER, rough endoplasmic reticulum; arrows, desmosomes; asterisks, heterochromatin aggregates. 


\section{$1,25(\mathrm{OH})_{2} \mathrm{D}_{3}$}
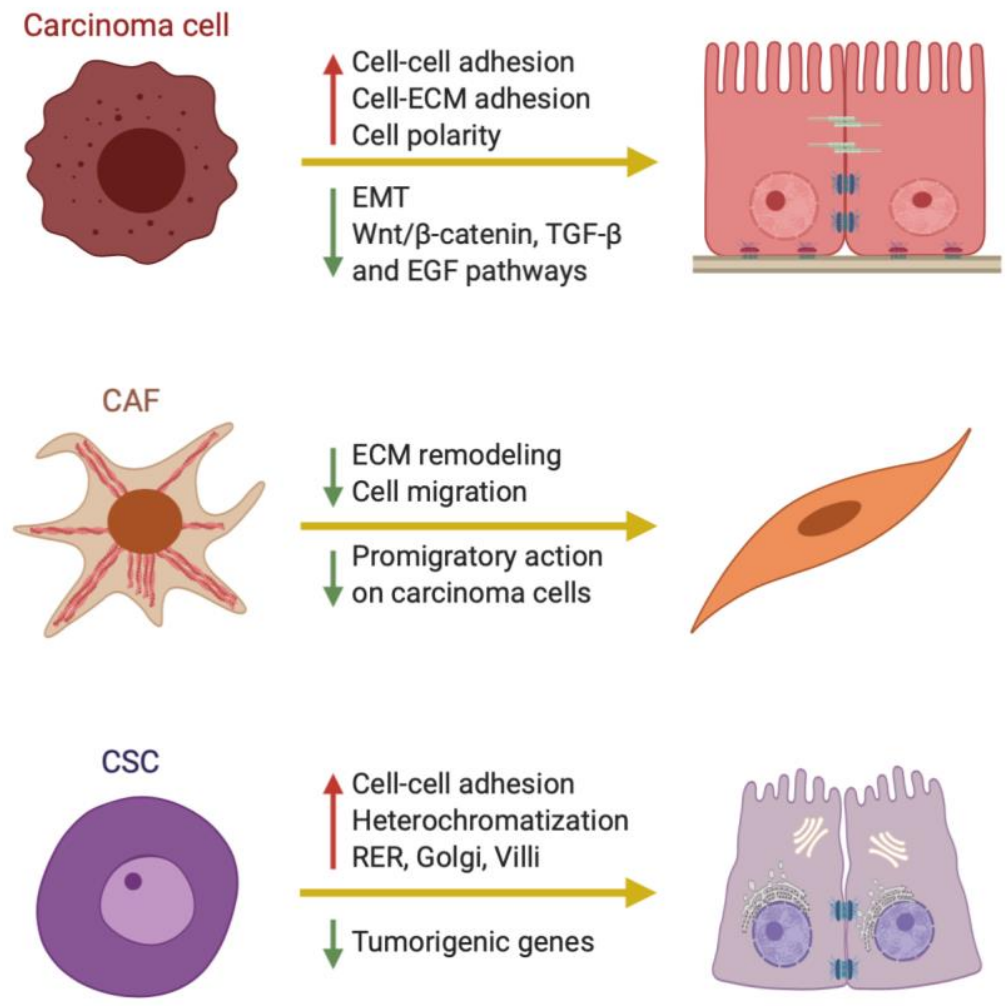

Figure 2. Schematic representation of the mechanisms by which $1,25(\mathrm{OH})_{2} \mathrm{D}_{3}$ regulates the differentiation of human colon carcinoma cells, cancer-associated fibroblasts (CAFs) and cancer stem cells (CSCs).

TGF- $\beta$ is a strong inhibitor of epithelial cell proliferation and a major inducer of EMT-TFs in many cell systems. $1,25(\mathrm{OH})_{2} \mathrm{D}_{3}$ inhibits the induction of EMT by TGF- $\beta$ in normal epithelial cells, which prevents the downregulation of E-cadherin [26]. Notably, TGF- $\beta$ signaling is inactivated by mutation of TGFBR2/TGF- $\beta$ receptor type II in around $30 \%$ of colon cancers or, less frequently, by that of the signal transducers SMAD2 or SMAD4, which limits the EMT-promoting role of TGF- $\beta$ in this neoplasia. However, Chen et al. reported that $1,25(\mathrm{OH})_{2} \mathrm{D}_{3}$ attenuates the induction of EMT by TGF- $\beta$ in colon carcinoma cells and inhibits SNAIL1 and SNAIL2 expression, the E-cadherin/N-cadherin switch, and the secretion of MMP2 and MMP9 [27]. Likewise, 1,25(OH) $)_{2} \mathrm{D}_{3}$ reduces the induction of EMT by interleukin- $1 \beta$ via repression of the long noncoding RNA lncTCF7 [28].

Antagonism of the Wnt $/ \beta$-Catenin Signaling Pathway by $1,25(\mathrm{OH})_{2} \mathrm{D}_{3}$

The Wnt/ $\beta$-catenin signaling pathway is abnormally activated by mutations in APC, or less frequently in CTNNB1/ $\beta$-catenin or other genes, in nearly all primary human colon tumors and their metastases $[29,30]$. In addition, autocrine or paracrine stimulation by Wnt factors and diminished expression of Wnt inhibitors, such as members of the dickkopf (DKK) and secreted frizzled-related protein families, may potentiate this pathway [31]. As a result of these alterations, $\beta$-catenin protein accumulates within the cell nucleus of colon epithelial cells and acts as a transcriptional regulator, forming complexes with members of the T-cell factor (TCF) family and activating a specific gene expression program that largely coincides with that of normal intestinal stem cells [32]. This leads to epithelial dedifferentiation, induction of EMT and acquisition of stemness. Thus, abnormal Wnt/ $\beta$-catenin pathway activation is responsible for the initiation and probably also for the progression 
of colon cancer via the increase in colon epithelial cell survival and proliferation and the loss of the differentiated phenotype [31-33].

First in colon carcinoma cells and later in other types of cancer cells, $1,25(\mathrm{OH})_{2} \mathrm{D}_{3}$ has been shown to antagonize the activation of the $\mathrm{Wnt} / \beta$-catenin pathway at several levels [34]. Ligand-activated nuclear VDR binds to the $\beta$-catenin protein, which hampers the formation of transcriptionally competent $\beta$-catenin-TCF complexes and thus blocks the expression of their target genes [16,35]. In addition, $1,25(\mathrm{OH})_{2} \mathrm{D}_{3}$ induces $D K K-1$ gene expression, which encodes an extracellular inhibitor of Wnt signaling that acts on Wnt receptor complexes at the cell surface [36]. Another mechanism of Wnt/ $\beta$-catenin pathway inactivation by $1,25(\mathrm{OH})_{2} \mathrm{D}_{3}$ derives from increased accumulation of the E-cadherin protein, which, due to its high affinity, sequesters the newly synthesized cytosolic $\beta$-catenin protein at the subcortical/surface adherens junctions [16] (Figure 1a). However, this mechanism is non-essential, as $1,25(\mathrm{OH})_{2} \mathrm{D}_{3}$ inhibits the $\mathrm{Wnt} / \beta$-catenin pathway even in cells that lack E-cadherin expression [16].

Other mechanisms of $\mathrm{Wnt} / \beta$-catenin pathway deactivation by $1,25(\mathrm{OH})_{2} \mathrm{D}_{3}$ have been proposed: the induction of TCF4 in colon and breast carcinoma cells [37], and a paracrine action decreasing the production and release by stromal macrophages of interleukin- $1 \beta$, a cytokine that inhibits the phosphorylation-mediated degradation of $\beta$-catenin protein and so increases $\beta$-catenin-TCF transcriptional activity in colon carcinoma cells [38]. In addition, in the non-malignant LT97 colon adenoma cell line, $1,25(\mathrm{OH})_{2} \mathrm{D}_{3}$ reduces the level of nuclear $\beta$-catenin and increases cellular differentiation [39].

The relevance of the vitamin D system for Wnt/ $\beta$-catenin activity in colon cancer in vivo was first studied in animals. Larriba et al. [40] and Zheng et al. [41] reported that the absence of Vdr ( $V d r$-deficient mice) increases colonic tumor burden and the amount of nuclear $\beta$-catenin protein in colon cancer cells in the Apc $\mathrm{Min} /+$ colon cancer mouse model. These findings support a role of $\mathrm{VDR} / 1,25(\mathrm{OH})_{2} \mathrm{D}_{3}$ in repressing the Wnt $/ \beta$-catenin pathway and the growth of intestinal tumors. More importantly, in a randomized, double-blinded, placebo-controlled clinical trial, Bostick et al. showed that supplementation with vitamin $\mathrm{D}_{3}$ increases the expression of E-cadherin and CASR, as well as other differentiation markers and potentially protective genes, in the healthy colon mucosa of patients with colorectal adenomas [42,43]. These authors also found an increase in the APC/ $\beta$-catenin ratio in the colonic mucosa of the vitamin $\mathrm{D}_{3}$-supplemented group, which is compatible with an inhibitory effect of vitamin $\mathrm{D}_{3}$ on the $\mathrm{Wnt} / \beta$-catenin pathway [44].

Other $1,25(\mathrm{OH})_{2} \mathrm{D}_{3}$ Target Genes Are Involved in Colon Cancer Cell Differentiation

Work by our group has led to the identification of several mediators of the prodifferentiation action of $1,25(\mathrm{OH})_{2} \mathrm{D}_{3}$ in colon carcinoma cells. These mediators include cystatin $\mathrm{D}$, miR-22, KDM6B and Sprouty-2 (SPRY2).

Cystatin D is a multifunctional protein that acts as a cysteine protease inhibitor in the cytosol and extracellular region and as a transcriptional regulator within the cell nucleus [45]. The transcription of the CST5 gene, encoding cystatin $\mathrm{D}$, is strongly induced by $1,25(\mathrm{OH})_{2} \mathrm{D}_{3}$ in colon carcinoma cells via direct binding of VDR to its promoter region [46]. Remarkably, cystatin D overexpression induces the expression of E-cadherin, occludin and other adhesion proteins, and represses that of several genes encoding EMT-TFs (SNAI1, SNAI2, ZEB1, ZEB2). Moreover, cystatin D antagonizes the Wnt/ $\beta$-catenin pathway and inhibits colon carcinoma cell proliferation and migration [46].

In a microarray-based study, we identified several microRNAs (miRs) regulated by $1,25(\mathrm{OH})_{2} \mathrm{D}_{3}$ in SW480-ADH human colon carcinoma cells. One of these targets is miR-22, which is induced by $1,25(\mathrm{OH})_{2} \mathrm{D}_{3}$ and contributes to the effects of $1,25(\mathrm{OH})_{2} \mathrm{D}_{3}$ on gene expression and cell proliferation and migration [47]. Subsequently, other groups have reported that miR-22 inhibits EMT, invasiveness and tumor growth in colon cancer and a few other cancer systems $[48,49]$.

KDM6B is an enzyme that demethylates di- and tri-methyl-lysine 27 on histone $\mathrm{H} 3$ (H3K27me2/3), an epigenetic mark that usually correlates with gene repression. Thus, KDM6B is expected to enable the activation of genes, although this histone demethylase appears to have additional transcriptional 
effects unrelated to histone demethylation. We found that $1,25(\mathrm{OH})_{2} \mathrm{D}_{3}$ upregulates the $K D M 6 B$ gene by activating its promoter, and that $K D M 6 B$ knockdown reduces the induction of E-cadherin and cell differentiation and the inhibition of $\beta$-catenin transcriptional activity promoted by $1,25(\mathrm{OH})_{2} \mathrm{D}_{3}$ in colon carcinoma cells [50]. KDM6B knockdown also upregulates SNAIL1 and ZEB1, the latter possibly through the decrease of $m i R-200 b$ and $m i R-200 c$, and it downregulates the adhesion proteins E-cadherin, claudin-1 and -7 [50,51].

SPRY 2 was found to be a gene that is strongly repressed by $1,25(\mathrm{OH})_{2} \mathrm{D}_{3}$ in a microarray analysis performed in SW480-ADH cells [18]. Its encoded protein is a modulator of tyrosine kinase receptor signaling, with receptor- and cell type-dependent inhibitory or enhancing effects. Thus, SPRY2 inhibits fibroblast growth factor signaling but potentiates the activation of RAS-ERK by epidermal growth factor (EGF). In human colon carcinoma cells, SPRY2 promotes EMT through the upregulation of ZEB1 and the downregulation of epithelial splicing regulator ESRP1. Consequently, SPRY2 represses CDH1/E-cadherin and genes encoding the tight junction proteins claudin-7 and occludin, as well as the important regulators of the polarized epithelial phenotype LLGL2, PATJ and ST14 [52,53]. SPRY2 expression is induced by $\beta$-catenin in cooperation with the transcription factor FOXO3a. Accordingly, it correlates with nuclear $\beta$-catenin and FOXO3a colocalization in human colon carcinomas and is indicative of poor prognosis [54]. In summary, our data indicate that repression of SPRY2 makes an important contribution to the prodifferentiation action of $1,25(\mathrm{OH})_{2} \mathrm{D}_{3}$.

Crosstalk between $1,25(\mathrm{OH})_{2} \mathrm{D}_{3}$ and EMT

The above data clearly indicate that $1,25(\mathrm{OH})_{2} \mathrm{D}_{3}$ promotes epithelial differentiation and inhibits EMT in colon carcinoma cells. Conversely, it has been shown that SNAIL1 and SNAIL2 repress VDR expression and abolish 1,25(OH $)_{2} \mathrm{D}_{3}$ responsiveness [55-57]. Thus, $1,25(\mathrm{OH})_{2} \mathrm{D}_{3}$ and EMT are reciprocally downregulated and the balance between $1,25(\mathrm{OH})_{2} \mathrm{D}_{3}$ and EMT-inducing signals determines cell phenotype. Supporting this, VDR RNA expression correlates directly with differentiation and inversely with SNAI1 and SNAI2 RNA expression in human colon tumors [55,57-60]. In addition to the mechanisms described in previous sections, the mutual antagonism between $1,25(\mathrm{OH})_{2} \mathrm{D}_{3}$ and EMT is probably also a consequence of the multilevel cross-inhibition of $1,25(\mathrm{OH})_{2} \mathrm{D}_{3}$ and the EMT-inducing pathways Wnt/ $\beta$-catenin, TGF- $\beta$ and EGF $[34,61,62]$ (Figure 2). For example, by repressing SPRY2 and inducing E-cadherin, which downregulates EGFR [63], 1,25(OH ${ }_{2} \mathrm{D}_{3}$ may inhibit EGF signaling. In addition, cross-inhibition of VDR and EGFR has been described in colon carcinoma cells [64-66]. Similar functional crosstalk applies to $1,25(\mathrm{OH})_{2} \mathrm{D}_{3}$ and insulin-like growth factor (IGF)-I [61].

\subsubsection{Breast Cancer}

Breast cancer is a highly heterogeneous disease. Two key studies have respectively proposed five or ten molecular subtypes on the basis of a global gene expression study [67] or a more comprehensive genomic and transcriptomic analysis [68]. Analyzing the expression of estrogen receptor (ER), progesterone receptor (PR), and epidermal growth factor receptor 2 (ERBB2, NEU or HER2) is still the basis for breast cancer stratification and an important determinant of breast carcinoma cell phenotype. Cancers that lack or express very low levels of ER, PR and HER2 proteins (triple negative breast cancers or TNBC) have the poorest prognosis and, concordantly, ER- PR ${ }^{-}$HER2 ${ }^{-}$cells are highly dedifferentiated (anaplastic). Interestingly, TNBC patients have very low 25(OH)D blood levels and some in vitro and clinical studies suggest the possibility of a protective effect of $1,25(\mathrm{OH})_{2} \mathrm{D}_{3}$ against TNBC [69].

$1,25(\mathrm{OH})_{2} \mathrm{D}_{3}$ contributes to the normal development and function of the mammary gland [70]. Accordingly, VDR is expressed in normal breast tissue and in many, but not all, breast carcinoma cell lines and tumors [71-74]. Several excellent reviews have summarized the effects of $1,25(\mathrm{OH})_{2} \mathrm{D}_{3}$ on breast cancer cells, animal models and patients $[70,75-77]$. The study of $1,25(\mathrm{OH})_{2} \mathrm{D}_{3}$ effects in a panel of human breast carcinoma cell lines revealed that it induces a cell-specific change in morphology (Figure $1 \mathrm{~b}$ ) and gene expression. In some cases, $1,25(\mathrm{OH})_{2} \mathrm{D}_{3}$ alters the cytoarchitecture of actin 
filaments and microtubules and induces cytoplasmic extensions (filopodia and lamellipodia). It also increases adhesion to substrate by promoting the accumulation of focal adhesion kinase, paxillin and $\alpha_{v^{-}}$and $\beta_{5}$-integrins in focal adhesion plaques. Additionally, in several cell lines $1,25(\mathrm{OH})_{2} \mathrm{D}_{3}$ upregulates E-cadherin and represses the myoepithelial proteins P-cadherin, smooth muscle $\alpha$-actin and $\alpha_{6}$ - and $\beta_{4}$-integrins [72,78]. Other studies have described the inhibition by $1,25(\mathrm{OH})_{2} \mathrm{D}_{3}$ of breast carcinoma cell migration, invasion and metastatic capacities via a reduction in the expression and/or the activity of $\mathrm{N}$-cadherin, the ECM components tenascin $\mathrm{C}$ and periostin, several metalloproteases (MMP-1, MMP-9) and serine proteases (plasminogen activator), as well as the induction of their inhibitors [79-84]. In addition, upregulation of the actin cytoskeleton adaptor protein PDLIM2 is crucial for the pro-adhesive, antimigratory and anti-invasive actions of $1,25(\mathrm{OH})_{2} \mathrm{D}_{3}$ in breast cancer cells [85]. In contrast to its induction in colon carcinoma cells [24], 1,25(OH $)_{2} \mathrm{D}_{3}$ suppresses the expression of ID-1 in human breast carcinoma cells and xenografted tumors, which conceivably contributes to promoting differentiation [86].

\subsubsection{Other Solid Cancers}

As in colon and breast cancers, $1,25(\mathrm{OH})_{2} \mathrm{D}_{3}$ induces cell differentiation, sensitizes to apoptosis and inhibits proliferation, migration and invasion in a series of other solid neoplasias. Again, its effects on differentiation are largely due to inhibition of the EMT and antagonism of the Wnt/ $\beta$-catenin, EGF and TGF- $\beta$ pathways.

The antagonism of the Wnt/ $\beta$-catenin pathway by $1,25(\mathrm{OH})_{2} \mathrm{D}_{3}$ has been described in several solid cancers as a consequence of a variety of mechanisms: (1) by promoting the lysosomal degradation of LRP6, a member of the Wnt surface receptor complex, in pancreatic adenocarcinoma cells [87]; (2) via ligand-activated VDR- $\beta$-catenin interaction in renal carcinoma cells [88] and mouse skin tumorigenesis [89,90]; and (3) via ligand-activated VDR- $\beta$-catenin interaction and DKK-1 induction in Kaposi's sarcoma cells [91]. The inhibition of the TGF- $\beta$ pathway by $1,25(\mathrm{OH})_{2} \mathrm{D}_{3}$ and other VDR agonists and the subsequent repression of EMT-TFs and upregulation of epithelial markers have been reported in anaplastic thyroid cancer cells [92], ovarian cancer cells [93], lung adenocarcinoma cells [94] and renal carcinoma cells [88]. Likewise, VDR agonists repress EGF signaling in squamous cell carcinoma cells [95], epidermoid cells [96] and psoriatic keratinocytes [97].

Altogether, these effects show that $1,25(\mathrm{OH})_{2} \mathrm{D}_{3}$ is a strong, multifaceted promotor of human carcinoma cell differentiation. As discussed by Gocek and Studzinski [75], the prodifferentiation effect of $1,25(\mathrm{OH})_{2} \mathrm{D}_{3}$ on carcinoma cells does not result in the restoration of a complete normal epithelial phenotype, but it probably has an antitumor action due to the associated diminution of carcinoma cell proliferation; survival; and migratory, invasive and metastatic capacities.

\subsection{Effects of $1,25(\mathrm{OH})_{2} \mathrm{D}_{3}$ on the Differentiation of Hematological Cancer Cells}

As in solid cancers, vitamin D deficiency is common among patients with hematological malignancies, and 1,25(OH) ${ }_{2} \mathrm{D}_{3}$ and other VDR agonists inhibit the proliferation of leukemia, lymphoma and myeloma cells, as well as favoring their apoptosis upon cytotoxic treatments. A widely reported effect of $1,25(\mathrm{OH})_{2} \mathrm{D}_{3}$ in these cells is the inhibition of STAT-1 and STAT-3 signaling and the subsequent repression of a large number of cytokines [75,98]. However, the induction of differentiation seems to be a less important protective mechanism of $1,25(\mathrm{OH})_{2} \mathrm{D}_{3}$ in hematological malignancies than in solid cancers. Although VDR is expressed by all immune cell types, $1,25(\mathrm{OH})_{2} \mathrm{D}_{3}$ induces differentiation of myeloid leukemia cells almost exclusively $[99,100]$. Most results have been obtained in the acute myeloid leukemia (AML) cell lines HL60, THP-1 and U937. Thus, $1,25(\mathrm{OH})_{2} \mathrm{D}_{3}$ increases the expression of markers of the monocyte-macrophage phenotype, such as CD14 and some proteins involved in phagocytosis and adherence to the substratum, including CD11b [75,98]. A number of genes and proteins have been proposed as mediators of this prodifferentiation action of $1,25(\mathrm{OH})_{2} \mathrm{D}_{3}$, such as $C E B P B$ and $C D K N 1 A$, which respectively encode the CCAAT enhancer binding protein $\beta$ transcription factor and the $\mathrm{p} 21^{\mathrm{CIP} 1}$ cyclin-dependent kinase inhibitor [101-103]. Other studies have proposed ERK, 
JNK, PI3K and PKC- $\alpha$ and $-\beta$ as cytosolic mediators of these $1,25(\mathrm{OH})_{2} \mathrm{D}_{3}$ effects [104-106]. Notably, Muto et al. reported that $1,25(\mathrm{OH})_{2} \mathrm{D}_{3}$ induces differentiation of the retinoic acid-resistant acute promyelocytic leukemia UF-1 cell line, associated with the expression of the $\mathrm{p} 21^{\mathrm{CIP} 1}$ and $\mathrm{p} 27^{\mathrm{KIP} 1}$ cell cycle inhibitors [107]. Prodifferentiation effects of VDR agonists have also been reported in follicular non-Hodgkin's lymphoma SU-DHL4 cells, with increased expression of mature B-cell markers [108].

\section{Effects of $1,25(\mathrm{OH})_{2} D_{3}$ on the Differentiation of Tumor Stromal Fibroblasts}

Although the crucial importance of the tumor microenvironment during all stages of carcinogenesis is today widely accepted, studies on the action of $1,25(\mathrm{OH})_{2} \mathrm{D}_{3}$ on tumor stromal cells are scarce. Cancer-associated fibroblasts (CAFs) are the most abundant cell type in the tumor microenvironment. Recent data indicate that CAFs are a heterogeneous population of cells generated from diverse origins in response to signals secreted by tumor cells or by other cells of the tumor stroma. Thus, they can originate from the phenotypic change (activation) of resident fibroblasts, from the recruitment and activation of bone marrow-derived fibrocytes and mesenchymal stem cells, or from the transdifferentiation of other cell types (epithelial, endothelial or smooth muscle cells, adipocytes or pericytes) $[109,110]$. Usually, but not always, CAFs have tumor promoter effects that favor the malignancy of cancer cells by altering the ECM and secreting protumorigenic and drug-resistance factors $[109,111]$.

Several strategies for CAF-directed anticancer therapy are possible [110]. Since CAF elimination unexpectedly rendered an acceleration of pancreatic cancer [112,113], the option of their deactivation or reprogramming to a less protumorigenic phenotype has become attractive. In this context, the VDR agonist calcipotriol has been reported to inhibit pancreatic stellate cell activation and differentiation into myofibroblasts, and thus to reduce inflammation and fibrosis in a pancreatitis mouse model and to enhance the efficacy of anticancer therapy in a pancreatic cancer model [114]. Likewise, calcipotriol reduces liver inflammation and fibrosis through the inhibition of hepatic stellate cell activation $[115,116]$. Accordingly, other protective effects of $1,25(\mathrm{OH})_{2} \mathrm{D}_{3}$ against fibrosis have been described and summarized elsewhere [62].

A global gene expression study, performed with human CAFs isolated from tumor biopsies of five breast cancer patients, identified 123 genes regulated by $1,25(\mathrm{OH})_{2} \mathrm{D}_{3}$ [117]. This gene signature reflects an antiproliferative and anti-inflammatory effect of $1,25(\mathrm{OH})_{2} \mathrm{D}_{3}$, as it includes the downregulation of the growth factor NRG1 and other genes with proliferation promotion effects, as well as the upregulation of DUSP1 (a phosphatase that inactivates MAPKs) and NFKBIA (an inhibitor of NFkB). In paired normal fibroblasts $(\mathrm{NFs}), 1,25(\mathrm{OH})_{2} \mathrm{D}_{3}$ modulates the expression of 126 genes ( $55 \%$ of them are also regulated by $1,25(\mathrm{OH})_{2} \mathrm{D}_{3}$ in $\mathrm{CAFs}$ ), including among the upregulated genes a few involved in antiproliferative, apoptosis and differentiation processes [117]. However, this study lacked functional analyses.

More recently, a study designed to characterize the effects of $1,25(\mathrm{OH})_{2} \mathrm{D}_{3}$ on colon cancer stromal fibroblasts rendered some interesting data [118]. First, the analysis of tumor biopsies from 658 patients showed that high VDR expression in CAFs is associated with better patient overall and progression-free survival, independently of the level of VDR expression in carcinoma cells. Second, a global gene expression analysis of seven primary cultures of CAFs and NFs established from colon cancer patient biopsies revealed that $1,25(\mathrm{OH})_{2} \mathrm{D}_{3}$ imposes in CAFs a 48-gene signature that correlates with longer patient survival in several colon cancer cohorts. Around one thousand genes are regulated by $1,25(\mathrm{OH})_{2} \mathrm{D}_{3}$ in CAFs and NFs, with a $21 \%$ overlap. The identified $1,25(\mathrm{OH})_{2} \mathrm{D}_{3}$ target genes are involved in cell adhesion, differentiation and migration; tissue remodeling; blood vessel development and inflammatory response. These genes encode mainly for ECM components and cytokines. Third, $1,25(\mathrm{OH})_{2} \mathrm{D}_{3}$ inhibits two protumoral properties in CAFs and in NFs: the paracrine promigratory action on carcinoma cells and the capacity to contract collagen gels, which is considered a hallmark of fibroblastic activation [118] (Figure 2). These results show that $1,25(\mathrm{OH})_{2} \mathrm{D}_{3}$ promotes profound reprogramming of the CAF gene expression profile, which leads to inhibition of their protumoral phenotype and contributes to protection against colon cancer. In addition, this study reveals that $1,25(\mathrm{OH})_{2} \mathrm{D}_{3}$ attenuates the malignant phenotype of colon carcinoma cells not only via a direct effect 
on these cells, but also indirectly through the de-activation of CAFs. Concordantly, the analysis of a large cohort of colon cancer patients indicated that the expression of VDR in CAFs and carcinoma cells has an additive protective effect, extending the overall survival of patients [118]. These findings are clinically relevant, as they indicate that colon cancer patients may benefit from an adequate vitamin $\mathrm{D}$ status or from treatment with VDR agonists, provided their CAFs express VDR, even though their carcinoma cells may be VDR-deficient, for instance due to SNAIL1 and/or SNAIL2 upregulation.

Remarkably, the regulation by $1,25(\mathrm{OH})_{2} \mathrm{D}_{3}$ of signaling molecules (cytokines, growth factors) secreted by CAFs suggests that it may also affect the biology of carcinoma cells and other cell types in the tumor microenvironment, such as immune and endothelial cells, in a paracrine manner. In line with these data, Kong et al. [119] reported that $1,25(\mathrm{OH})_{2} \mathrm{D}_{3}$ decreases the amount of miR-10a-5p found in the exosomes secreted by human pancreatic $\mathrm{CAFs}$, which attenuates the promigratory and pro-invasive effects that these CAFs exert on pancreatic carcinoma cells. Notably, the possible interplay between $1,25(\mathrm{OH})_{2} \mathrm{D}_{3}$ and Wnt $3 \mathrm{~A}$ in colon fibroblasts has also been reported. Both agents are strong regulators of the gene expression profile and phenotype of these cells. However, in contrast to the antagonism reported in carcinoma cells, they have an additive and partially overlapping effect $[120,121]$.

These results show that $1,25(\mathrm{OH})_{2} \mathrm{D}_{3}$ action extends to tumor stromal fibroblasts and that $1,25(\mathrm{OH})_{2} \mathrm{D}_{3}$ is an important regulator of CAF differentiation. Together with other findings suggesting anti-inflammatory and anti-angiogenic effects of $1,25(\mathrm{OH})_{2} \mathrm{D}_{3}$ at the level of immune and endothelial cells [122], they widen the prodifferentiation action of $1,25(\mathrm{OH})_{2} \mathrm{D}_{3}$ to cells of the tumor microenvironment, which may have important consequences on cancer development.

\section{Effects of $1,25(\mathrm{OH})_{2} \mathrm{D}_{3}$ on Cancer Stem Cells}

The concept of cancer stem cells (CSCs) states that tumors are initiated, progress and probably become resistant to therapies due to the accumulation of genetic and epigenetic alterations in tissue stem cells that become CSCs. This has led to investigations focused on identifying markers of undifferentiated stem cells in each tissue that could be used to isolate and specifically target CSCs with appropriate drugs or antibodies. However, although some relatively selective markers have been identified in a few cancer types, the idea of culturing or targeting tumor-specific CSCs has clashed with the finding of stem cell plasticity. This term refers to the dedifferentiation of cells at intermediate or even terminal differentiation stages, in order to restore the stem cell compartment following a lethal injury in normal tissues, or as a consequence of the acquisition of genetic alterations, and/or in response to signals from the tumor microenvironment in cancer [123-125]. Thus, stemness is today considered a usually transient cellular state that is lost in the process of differentiation. Differentiated cells can re-acquire stemness properties when the stem cell reservoir needs to be regenerated. Consequently, no stable CSCs seem to exist within tumors that can be isolated and studied as optimal targets for anticancer therapies [126].

Several studies have reported that VDR agonists inhibit the formation of floating spheroids called mammospheres (a feature attributed to CSCs) in breast cancer stem-like cells obtained from established cell lines. Interestingly, this effect could be overcome by $\beta$-catenin overexpression, which suggests that the inhibition of the Wnt/ $\beta$-catenin pathway mediates this action of VDR agonists [127]. Likewise, in human triple negative and basal-like breast cancer cells, the $1,25(\mathrm{OH})_{2} \mathrm{D}_{3}$ analog BXL0124 reduces mammosphere-forming efficiency and downregulates the expression of stemness markers (OCT4, CD44) and Notch pathway genes (NOTCH1, JAG1/2) [128-130]. In addition, $1,25(\mathrm{OH})_{2} \mathrm{D}_{3}$ depleted the cancer stem-like cell subpopulation present in a human ovarian cancer cell line, thus reducing cell capacity to form spheres and initiate tumor formation. Additionally in this case, the main mechanism responsible for these effects of $1,25(\mathrm{OH})_{2} \mathrm{D}_{3}$ is antagonism of the $\mathrm{Wnt} / \beta$-catenin pathway [131]. $1,25(\mathrm{OH})_{2} \mathrm{D}_{3}$ reduced sphere formation and the RNA expression of several stem cell markers (Cd44, Nanog, Oct4, Sox2, Klf4 and Abcg2) in a stem-like subpopulation of mouse malignant ovarian epithelial cells [132]. Similarly, $1,25(\mathrm{OH})_{2} \mathrm{D}_{3}$ downregulates NANOG and OCT4 in embryonal carcinoma and seminoma cells [133]. 
The above studies share the weakness of analyzing $1,25(\mathrm{OH})_{2} \mathrm{D}_{3}$ effects on cell populations which are enriched in stem cell characteristics but which are isolated from immortalized cell lines that have been growing in culture for a long time. Organoids clearly resemble the in vivo situation more closely, as they are three-dimensional structures generated by primary normal or cancer stem cells isolated from patients on culturing. Our group has recently described the effects of $1,25(\mathrm{OH})_{2} \mathrm{D}_{3}$ on human colon normal and tumor organoids, generated from biopsies of healthy and tumor tissue obtained from colon cancer patients [134]. Remarkably, $1,25(\mathrm{OH})_{2} \mathrm{D}_{3}$ induces cell differentiation in colon tumor organoids by changing their typical blastic cell appearance to a more epithelial differentiated phenotype that includes cell-cell adhesion structures, heterochromatin, villi, abundant rough endoplasmic reticulum, Golgi complexes and autophagic vacuoles [134] (Figure 1c). Global transcriptomic RNA-seq analysis revealed that $1,25(\mathrm{OH})_{2} \mathrm{D}_{3}$ promotes an enrichment in the colon differentiation signature EPHB2 ${ }^{\text {low }}$ vs. EPHB2 ${ }^{\text {high }}$ in colon tumor organoids, as well as the repression of genes involved in proliferation and tumorigenesis (Figure 2). However, unexpectedly, $1,25(\mathrm{OH})_{2} \mathrm{D}_{3}$ does not substantially modulate the expression of stemness or $\mathrm{Wnt} / \beta$-catenin target genes. Contrarily, in colon normal organoids, $1,25(\mathrm{OH})_{2} \mathrm{D}_{3}$ upregulates several key stemness genes (LGR5, SMOC2, LRIG1, MSI1, PTK7 and MEX3A) and, concordantly, it does not affect the undifferentiated cell phenotype [134]. Importantly, recent RNA-seq analyses showed that $1,25(\mathrm{OH})_{2} \mathrm{D}_{3}$ has very similar effects on the global pattern of gene expression in colon and rectum normal organoids [135]. Likewise, the transcriptomic profiles induced by $1,25(\mathrm{OH})_{2} \mathrm{D}_{3}$ in colon and rectal tumor organoids are highly comparable [135]. As occurs in colon tissue [134], 1,25(OH $)_{2} \mathrm{D}_{3}$ upregulates LGR5, LRIG1, SMOC2 and MSI1 stemness genes and downregulates the differentiation genes MUC2 and TFF2 in normal rectum organoids, but not in rectal tumor organoids, which indicates a homeostatic action of $1,25(\mathrm{OH})_{2} \mathrm{D}_{3}$ on the normal stem cell population in both intestinal areas (colon and rectum) [135]. Accordingly, studies by Augenlicht's group have revealed that feeding mice with a low vitamin $\mathrm{D}_{3}$ and calcium diet or specific-inactivation of $V d r$ in Lgr5 ${ }^{+}$intestinal stem cells compromises stem cell properties and function, and thus alters the maturation of $\mathrm{Lgr5}^{+}$progeny and intestinal homeostasis [136-138]. Interestingly, in human colon carcinoma cell lines, the $m i R-372 / 373$ cluster, which is upregulated by the $\mathrm{Wnt} / \beta$-catenin pathway and enhances stemness, has been found to downregulate VDR RNA and a panel of differentiation genes [139]. Together, these results indicate that $1,25(\mathrm{OH})_{2} \mathrm{D}_{3}$ exerts a homeostatic action in colon normal stem cells and a prodifferentiation effect on colon CSCs.

Recently, reduced VDR expression has been found to be associated with impaired myeloid progenitor differentiation and a poor prognostic factor in AML. The observed VDR repression is mainly due to gene promoter methylation, blocking differentiation and promoting self-renewal and proliferation in myeloid precursor cells. Accordingly, VDR agonists inhibit cell stemness in normal bone marrow and AML [140].

\section{Conclusions}

The active vitamin D metabolite $1,25(\mathrm{OH})_{2} \mathrm{D}_{3}$ and other synthetic VDR agonists are differentiation agents that enforce an epithelial state in carcinoma cells largely through the induction of key epithelial proteins and the inhibition of EMT. Work done predominantly in colon and breast cancer shows that the latter is mainly a consequence of the antagonism that these molecules exert on $\mathrm{Wnt} / \beta$-catenin, TGF- $\beta$ and EGF signaling pathways. Additionally, $1,25(\mathrm{OH})_{2} \mathrm{D}_{3}$ profoundly changes the gene expression profile of tumor stromal fibroblasts. It attenuates their activated phenotype and decreases their protumoral effects. It also exerts prodifferentiation actions on CSCs. Collectively, these data indicate that $1,25(\mathrm{OH})_{2} \mathrm{D}_{3}$, or VDR agonists in general, are candidates for cancer differentiation strategies.

Funding: The work in the authors' laboratory is funded by the Agencia Estatal de Investigación (PID2019-104867RB-I00/AEI/10.13039/501100011033), the Agencia Estatal de Investigación-Fondo Europeo de Desarrollo Regional (SAF2016-76377-R, MINECO/AEI/FEDER, EU), the Ministerio de Economía y Competitividad (SAF2017-90604-REDT/NuRCaMeIn), and the Instituto de Salud Carlos III-Fondo Europeo de Desarrollo Regional (CIBERONC; CB16/12/00273). 
Acknowledgments: We thank Miguel Lafarga for his continuous support and help with microscopy analyses, and Lucille Banham for her valuable assistance in the preparation of the English manuscript.

Conflicts of Interest: The authors declare no conflict of interest. The funders had no role in the writing of the manuscript or in the decision to publish it.

\section{References}

1. Fleet, J.C.; DeSmet, M.; Johnson, R.; Li, Y. Vitamin D and cancer: A review of molecular mechanisms. Biochem. J. 2012, 441, 61-76. [CrossRef] [PubMed]

2. Feldman, D.; Krishnan, A.V.; Swami, S.; Giovannucci, E.; Feldman, B.J. The role of vitamin D in reducing cancer risk and progression. Nat. Rev. Cancer 2014, 14, 342-357. [CrossRef] [PubMed]

3. Christakos, S.; Dhawan, P.; Verstuyf, A.; Verlinden, L.; Carmeliet, G. Vitamin D: Metabolism, Molecular Mechanism of Action, and Pleiotropic Effects. Physiol. Rev. 2016, 96, 365-408. [CrossRef] [PubMed]

4. Tuoresmaki, P.; Vaisanen, S.; Neme, A.; Heikkinen, S.; Carlberg, C. Patterns of genome-wide VDR locations. PLoS ONE 2014, 9, e96105. [CrossRef] [PubMed]

5. Campbell, M.J. Vitamin D and the RNA transcriptome: More than mRNA regulation. Front. Physiol. 2014, 5, 181. [CrossRef] [PubMed]

6. Carlberg, C.; Munoz, A. An update on vitamin D signaling and cancer. Semin. Cancer Biol. 2020, in press. [CrossRef]

7. Hanel, A.; Carlberg, C. Vitamin D and evolution: Pharmacologic implications. Biochem. Pharmacol. 2020, 173, 113595. [CrossRef]

8. Abe, E.; Miyaura, C.; Sakagami, H.; Takeda, M.; Konno, K.; Yamazaki, T.; Yoshiki, S.; Suda, T. Differentiation of mouse myeloid leukemia cells induced by 1 alpha,25-dihydroxyvitamin D3. Proc. Natl. Acad. Sci. USA 1981, 78, 4990-4994. [CrossRef]

9. Colston, K.; Colston, M.J.; Feldman, D. 1,25-dihydroxyvitamin D3 and malignant melanoma: The presence of receptors and inhibition of cell growth in culture. Endocrinology 1981, 108, 1083-1086. [CrossRef]

10. Nieto, M.A. Context-specific roles of EMT programmes in cancer cell dissemination. Nat. Cell Biol. 2017, 19, 416-418. [CrossRef]

11. Dongre, A.; Weinberg, R.A. New insights into the mechanisms of epithelial-mesenchymal transition and implications for cancer. Nat. Rev. Mol. Cell Biol. 2019, 20, 69-84. [CrossRef] [PubMed]

12. Yang, J.; Antin, P.; Berx, G.; Blanpain, C.; Brabletz, T.; Bronner, M.; Campbell, K.; Cano, A.; Casanova, J.; Christofori, G.; et al. Guidelines and definitions for research on epithelial-mesenchymal transition. Nat. Rev. Mol. Cell Biol. 2020, 21, 341-352. [CrossRef] [PubMed]

13. Grant, W.B. Review of Recent Advances in Understanding the Role of Vitamin D in Reducing Cancer Risk: Breast, Colorectal, Prostate, and Overall Cancer. Anticancer Res. 2020, 40, 491-499. [CrossRef] [PubMed]

14. Barbachano, A.; Fernandez-Barral, A.; Ferrer-Mayorga, G.; Costales-Carrera, A.; Larriba, M.J.; Munoz, A. The endocrine vitamin D system in the gut. Mol. Cell. Endocrinol. 2017, 453, 79-87. [CrossRef]

15. Christakos, S.; Li, S.; De La Cruz, J.; Shroyer, N.F.; Criss, Z.K.; Verzi, M.P.; Fleet, J.C. Vitamin D and the intestine: Review and update. J. Steroid Biochem. Mol. Biol. 2020, 196, 105501. [CrossRef]

16. Palmer, H.G.; Gonzalez-Sancho, J.M.; Espada, J.; Berciano, M.T.; Puig, I.; Baulida, J.; Quintanilla, M.; Cano, A.; de Herreros, A.G.; Lafarga, M.; et al. Vitamin D(3) promotes the differentiation of colon carcinoma cells by the induction of E-cadherin and the inhibition of beta-catenin signaling. J. Cell Biol. 2001, 154, 369-387. [CrossRef]

17. Ordonez-Moran, P.; Larriba, M.J.; Palmer, H.G.; Valero, R.A.; Barbachano, A.; Dunach, M.; de Herreros, A.G.; Villalobos, C.; Berciano, M.T.; Lafarga, M.; et al. RhoA-ROCK and p38MAPK-MSK1 mediate vitamin D effects on gene expression, phenotype, and Wnt pathway in colon cancer cells. J. Cell Biol. 2008, 183, 697-710. [CrossRef]

18. Palmer, H.G.; Sanchez-Carbayo, M.; Ordonez-Moran, P.; Larriba, M.J.; Cordon-Cardo, C.; Munoz, A. Genetic signatures of differentiation induced by 1alpha,25-dihydroxyvitamin D3 in human colon cancer cells. Cancer Res. 2003, 63, 7799-7806.

19. Fetahu, I.S.; Hummel, D.M.; Manhardt, T.; Aggarwal, A.; Baumgartner-Parzer, S.; Kallay, E. Regulation of the calcium-sensing receptor expression by 1,25-dihydroxyvitamin D3, interleukin-6, and tumor necrosis factor alpha in colon cancer cells. J. Steroid Biochem. Mol. Biol. 2014, 144, 228-231. [CrossRef] 
20. Aggarwal, A.; Hobaus, J.; Tennakoon, S.; Prinz-Wohlgenannt, M.; Graca, J.; Price, S.A.; Heffeter, P.; Berger, W.; Baumgartner-Parzer, S.; Kallay, E. Active vitamin D potentiates the anti-neoplastic effects of calcium in the colon: A cross talk through the calcium-sensing receptor. J. Steroid Biochem. Mol. Biol. 2016, 155, 231-238. [CrossRef]

21. Aggarwal, A.; Kallay, E. Cross Talk between the Calcium-Sensing Receptor and the Vitamin D System in Prevention of Cancer. Front. Physiol. 2016, 7, 451. [CrossRef]

22. Tennakoon, S.; Aggarwal, A.; Kallay, E. The calcium-sensing receptor and the hallmarks of cancer. Biochim. Biophys. Acta (BBA)-Bioenerg. 2016, 1863, 1398-1407. [CrossRef] [PubMed]

23. Yang, W.; Liu, L.; Masugi, Y.; Qian, Z.R.; Nishihara, R.; Keum, N.; Wu, K.; Smith-Warner, S.; Ma, Y.; Nowak, J.A.; et al. Calcium intake and risk of colorectal cancer according to expression status of calcium-sensing receptor (CASR). Gut 2018, 67, 1475-1483. [CrossRef] [PubMed]

24. Fernandez-Garcia, N.I.; Palmer, H.G.; Garcia, M.; Gonzalez-Martin, A.; del Rio, M.; Barettino, D.; Volpert, O.; Munoz, A.; Jimenez, B. 1alpha,25-Dihydroxyvitamin D3 regulates the expression of Id1 and Id2 genes and the angiogenic phenotype of human colon carcinoma cells. Oncogene 2005, 24, 6533-6544. [CrossRef]

25. Kouchi, Z.; Fujiwara, Y.; Yamaguchi, H.; Nakamura, Y.; Fukami, K. Phosphatidylinositol 5-phosphate 4-kinase type II beta is required for vitamin D receptor-dependent E-cadherin expression in SW480 cells. Biochem. Biophys. Res. Commun. 2011, 408, 523-529. [CrossRef] [PubMed]

26. Ricca, C.; Aillon, A.; Viano, M.; Bergandi, L.; Aldieri, E.; Silvagno, F. Vitamin D inhibits the epithelial-mesenchymal transition by a negative feedback regulation of TGF-beta activity. J. Steroid Biochem. Mol. Biol. 2019, 187, 97-105. [CrossRef] [PubMed]

27. Chen, S.; Zhu, J.; Zuo, S.; Ma, J.; Zhang, J.; Chen, G.; Wang, X.; Pan, Y.; Liu, Y.; Wang, P. 1,25(OH)2D3 attenuates TGF-beta1/beta2-induced increased migration and invasion via inhibiting epithelial-mesenchymal transition in colon cancer cells. Biochem. Biophys. Res. Commun. 2015, 468, 130-135. [CrossRef]

28. Li, T.; Zhu, J.; Zuo, S.; Chen, S.; Ma, J.; Ma, Y.; Guo, S.; Wang, P.; Liu, Y. 1,25(OH)2D3 Attenuates IL-1beta-Induced Epithelial-to-Mesenchymal Transition Through Inhibiting the Expression of lncTCF7. Oncol. Res. 2019, 27, 739-750. [CrossRef]

29. Cancer Genome Atlas Network. Comprehensive molecular characterization of human colon and rectal cancer. Nature 2012, 487, 330-337. [CrossRef]

30. Yaeger, R.; Chatila, W.K.; Lipsyc, M.D.; Hechtman, J.F.; Cercek, A.; Sanchez-Vega, F.; Jayakumaran, G.; Middha, S.; Zehir, A.; Donoghue, M.T.A.; et al. Clinical Sequencing Defines the Genomic Landscape of Metastatic Colorectal Cancer. Cancer Cell 2018, 33, 125-136.e123. [CrossRef]

31. Nusse, R.; Clevers, H. Wnt/beta-Catenin Signaling, Disease, and Emerging Therapeutic Modalities. Cell 2017, 169, 985-999. [CrossRef] [PubMed]

32. Merlos-Suarez, A.; Barriga, F.M.; Jung, P.; Iglesias, M.; Cespedes, M.V.; Rossell, D.; Sevillano, M.; Hernando-Momblona, X.; da Silva-Diz, V.; Munoz, P.; et al. The intestinal stem cell signature identifies colorectal cancer stem cells and predicts disease relapse. Cell Stem Cell 2011, 8, 511-524. [CrossRef] [PubMed]

33. Krausova, M.; Korinek, V. Wnt signaling in adult intestinal stem cells and cancer. Cell Signal. 2014, 26, 570-579. [CrossRef] [PubMed]

34. Larriba, M.J.; Gonzalez-Sancho, J.M.; Barbachano, A.; Niell, N.; Ferrer-Mayorga, G.; Munoz, A. Vitamin D Is a Multilevel Repressor of Wnt/b-Catenin Signaling in Cancer Cells. Cancers 2013, 5, 1242-1260. [CrossRef]

35. Shah, S.; Islam, M.N.; Dakshanamurthy, S.; Rizvi, I.; Rao, M.; Herrell, R.; Zinser, G.; Valrance, M.; Aranda, A.; Moras, D.; et al. The molecular basis of vitamin D receptor and beta-catenin crossregulation. Mol. Cell 2006, 21, 799-809. [CrossRef]

36. Aguilera, O.; Pena, C.; Garcia, J.M.; Larriba, M.J.; Ordonez-Moran, P.; Navarro, D.; Barbachano, A.; Lopez de Silanes, I.; Ballestar, E.; Fraga, M.F.; et al. The Wnt antagonist DICKKOPF-1 gene is induced by 1alpha,25-dihydroxyvitamin D3 associated to the differentiation of human colon cancer cells. Carcinogenesis 2007, 28, 1877-1884. [CrossRef]

37. Beildeck, M.E.; Islam, M.; Shah, S.; Welsh, J.; Byers, S.W. Control of TCF-4 expression by VDR and vitamin D in the mouse mammary gland and colorectal cancer cell lines. PLoS ONE 2009, 4, e7872. [CrossRef]

38. Kaler, P.; Augenlicht, L.; Klampfer, L. Macrophage-derived IL-1beta stimulates Wnt signaling and growth of colon cancer cells: A crosstalk interrupted by vitamin D3. Oncogene 2009, 28, 3892-3902. [CrossRef] 
39. Groschel, C.; Aggarwal, A.; Tennakoon, S.; Hobaus, J.; Prinz-Wohlgenannt, M.; Marian, B.; Heffeter, P.; Berger, W.; Kallay, E. Effect of 1,25-dihydroxyvitamin D3 on the Wnt pathway in non-malignant colonic cells. J. Steroid Biochem. Mol. Biol. 2016, 155, 224-230. [CrossRef]

40. Larriba, M.J.; Ordonez-Moran, P.; Chicote, I.; Martin-Fernandez, G.; Puig, I.; Munoz, A.; Palmer, H.G. Vitamin $\mathrm{D}$ receptor deficiency enhances Wnt/beta-catenin signaling and tumor burden in colon cancer. PLoS ONE 2011, 6, e23524. [CrossRef]

41. Zheng, W.; Wong, K.E.; Zhang, Z.; Dougherty, U.; Mustafi, R.; Kong, J.; Deb, D.K.; Zheng, H.; Bissonnette, M.; $\mathrm{Li}$, Y.C. Inactivation of the vitamin D receptor in $\mathrm{APC}(\mathrm{min} /+)$ mice reveals a critical role for the vitamin D receptor in intestinal tumor growth. Int. J. Cancer 2012, 130, 10-19. [CrossRef] [PubMed]

42. Bostick, R.M. Effects of supplemental vitamin D and calcium on normal colon tissue and circulating biomarkers of risk for colorectal neoplasms. J. Steroid Biochem. Mol. Biol. 2015, 148, 86-95. [CrossRef] [PubMed]

43. Fedirko, V.; Bostick, R.M.; Flanders, W.D.; Long, Q.; Sidelnikov, E.; Shaukat, A.; Daniel, C.R.; Rutherford, R.E.; Woodard, J.J. Effects of vitamin d and calcium on proliferation and differentiation in normal colon mucosa: A randomized clinical trial. Cancer Epidemiol. Biomark. Prev. 2009, 18, 2933-2941. [CrossRef] [PubMed]

44. Ahearn, T.U.; Shaukat, A.; Flanders, W.D.; Rutherford, R.E.; Bostick, R.M. A randomized clinical trial of the effects of supplemental calcium and vitamin D3 on the APC/beta-catenin pathway in the normal mucosa of colorectal adenoma patients. Cancer Prev. Res. 2012, 5, 1247-1256. [CrossRef]

45. Ferrer-Mayorga, G.; Alvarez-Diaz, S.; Valle, N.; De Las Rivas, J.; Mendes, M.; Barderas, R.; Canals, F.; Tapia, O.; Casal, J.I.; Lafarga, M.; et al. Cystatin D locates in the nucleus at sites of active transcription and modulates gene and protein expression. J. Biol. Chem. 2015, 290, 26533-26548. [CrossRef]

46. Alvarez-Diaz, S.; Valle, N.; Garcia, J.M.; Pena, C.; Freije, J.M.; Quesada, V.; Astudillo, A.; Bonilla, F.; Lopez-Otin, C.; Munoz, A. Cystatin D is a candidate tumor suppressor gene induced by vitamin D in human colon cancer cells. J. Clin. Investig. 2009, 119, 2343-2358. [CrossRef]

47. Alvarez-Diaz, S.; Valle, N.; Ferrer-Mayorga, G.; Lombardia, L.; Herrera, M.; Dominguez, O.; Segura, M.F.; Bonilla, F.; Hernando, E.; Munoz, A. MicroRNA-22 is induced by vitamin D and contributes to its antiproliferative, antimigratory and gene regulatory effects in colon cancer cells. Hum. Mol. Genet. 2012, 21, 2157-2165. [CrossRef]

48. Liu, Y.; Chen, X.; Cheng, R.; Yang, F.; Yu, M.; Wang, C.; Cui, S.; Hong, Y.; Liang, H.; Liu, M.; et al. The Jun/miR-22/HuR regulatory axis contributes to tumourigenesis in colorectal cancer. Mol. Cancer 2018, 17, 11. [CrossRef]

49. Xu, M.; Li, J.; Wang, X.; Meng, S.; Shen, J.; Wang, S.; Xu, X.; Xie, B.; Liu, B.; Xie, L. MiR-22 suppresses epithelial-mesenchymal transition in bladder cancer by inhibiting Snail and MAPK1/Slug/vimentin feedback loop. Cell Death Dis. 2018, 9, 209. [CrossRef]

50. Pereira, F.; Barbachano, A.; Silva, J.; Bonilla, F.; Campbell, M.J.; Munoz, A.; Larriba, M.J. KDM6B/JMJD3 histone demethylase is induced by vitamin D and modulates its effects in colon cancer cells. Hum. Mol. Genet. 2011, 20, 4655-4665. [CrossRef]

51. Pereira, F.; Barbachano, A.; Singh, P.K.; Campbell, M.J.; Munoz, A.; Larriba, M.J. Vitamin D has wide regulatory effects on histone demethylase genes. Cell Cycle 2012, 11, 1081-1089. [CrossRef] [PubMed]

52. Barbachano, A.; Ordonez-Moran, P.; Garcia, J.M.; Sanchez, A.; Pereira, F.; Larriba, M.J.; Martinez, N.; Hernandez, J.; Landolfi, S.; Bonilla, F.; et al. SPROUTY-2 and E-cadherin regulate reciprocally and dictate colon cancer cell tumourigenicity. Oncogene 2010, 29, 4800-4813. [CrossRef] [PubMed]

53. Barbachano, A.; Fernandez-Barral, A.; Pereira, F.; Segura, M.F.; Ordonez-Moran, P.; Pau, E.C.D.S.; Gonzalez-Sancho, J.M.; Hanniford, D.; Martinez, N.; Costales-Carrera, A.; et al. SPROUTY-2 represses the epithelial phenotype of colon carcinoma cells via upregulation of ZEB1 mediated by ETS1 and miR-200/miR-150. Oncogene 2016, 35, 2991-3003. [CrossRef] [PubMed]

54. Ordonez-Moran, P.; Irmisch, A.; Barbachano, A.; Chicote, I.; Tenbaum, S.; Landolfi, S.; Tabernero, J.; Huelsken, J.; Munoz, A.; Palmer, H.G. SPROUTY2 is a beta-catenin and FOXO3a target gene indicative of poor prognosis in colon cancer. Oncogene 2014, 33, 1975-1985. [CrossRef] [PubMed]

55. Palmer, H.G.; Larriba, M.J.; Garcia, J.M.; Ordonez-Moran, P.; Pena, C.; Peiro, S.; Puig, I.; Rodriguez, R.; de la Fuente, R.; Bernad, A.; et al. The transcription factor SNAIL represses vitamin D receptor expression and responsiveness in human colon cancer. Nat. Med. 2004, 10, 917-919. [CrossRef] [PubMed] 
56. Larriba, M.J.; Valle, N.; Palmer, H.G.; Ordonez-Moran, P.; Alvarez-Diaz, S.; Becker, K.F.; Gamallo, C.; de Herreros, A.G.; Gonzalez-Sancho, J.M.; Munoz, A. The inhibition of Wnt/beta-catenin signalling by 1alpha,25-dihydroxyvitamin D3 is abrogated by Snail1 in human colon cancer cells. Endocr. Relat. Cancer 2007, 14, 141-151. [CrossRef]

57. Larriba, M.J.; Martin-Villar, E.; Garcia, J.M.; Pereira, F.; Pena, C.; de Herreros, A.G.; Bonilla, F.; Munoz, A. Snail2 cooperates with Snail1 in the repression of vitamin D receptor in colon cancer. Carcinogenesis 2009, 30, 1459-1468. [CrossRef]

58. Pena, C.; Garcia, J.M.; Silva, J.; Garcia, V.; Rodriguez, R.; Alonso, I.; Millan, I.; Salas, C.; de Herreros, A.G.; Munoz, A.; et al. E-cadherin and vitamin D receptor regulation by SNAIL and ZEB1 in colon cancer: Clinicopathological correlations. Hum. Mol. Genet. 2005, 14, 3361-3370. [CrossRef]

59. Pena, C.; Garcia, J.M.; Garcia, V.; Silva, J.; Dominguez, G.; Rodriguez, R.; Maximiano, C.; de Herreros, A.G.; Munoz, A.; Bonilla, F. The expression levels of the transcriptional regulators p300 and CtBP modulate the correlations between SNAIL, ZEB1, E-cadherin and vitamin D receptor in human colon carcinomas. Int. J. Cancer 2006, 119, 2098-2104. [CrossRef]

60. Pena, C.; Garcia, J.M.; Larriba, M.J.; Barderas, R.; Gomez, I.; Herrera, M.; Garcia, V.; Silva, J.; Dominguez, G.; Rodriguez, R.; et al. SNAI1 expression in colon cancer related with CDH1 and VDR downregulation in normal adjacent tissue. Oncogene 2009, 28, 4375-4385. [CrossRef]

61. Larriba, M.J.; Gonzalez-Sancho, J.M.; Bonilla, F.; Munoz, A. Interaction of vitamin D with membrane-based signaling pathways. Front. Physiol. 2014, 5, 60. [CrossRef] [PubMed]

62. Larriba, M.J.; de Herreros, A.G.; Munoz, A. Vitamin D and the Epithelial to Mesenchymal Transition. Stem. Cells Int. 2016, 2016, 6213872. [CrossRef] [PubMed]

63. Andl, C.D.; Rustgi, A.K. No one-way street: Cross-talk between e-cadherin and receptor tyrosine kinase (RTK) signaling: A mechanism to regulate RTK activity. Cancer Biol. Ther. 2005, 4, 28-31. [CrossRef] [PubMed]

64. Tong, W.M.; Kallay, E.; Hofer, H.; Hulla, W.; Manhardt, T.; Peterlik, M.; Cross, H.S. Growth regulation of human colon cancer cells by epidermal growth factor and 1,25-dihydroxyvitamin D3 is mediated by mutual modulation of receptor expression. Eur. J. Cancer 1998, 34, 2119-2125. [CrossRef]

65. Tong, W.M.; Hofer, H.; Ellinger, A.; Peterlik, M.; Cross, H.S. Mechanism of antimitogenic action of vitamin $\mathrm{D}$ in human colon carcinoma cells: Relevance for suppression of epidermal growth factor-stimulated cell growth. Oncol. Res. 1999, 11,77-84. [PubMed]

66. Dougherty, U.; Mustafi, R.; Sadiq, F.; Almoghrabi, A.; Mustafi, D.; Kreisheh, M.; Sundaramurthy, S.; Liu, W.; Konda, V.J.; Pekow, J.; et al. The renin-angiotensin system mediates EGF receptor-vitamin d receptor cross-talk in colitis-associated colon cancer. Clin. Cancer Res. 2014, 20, 5848-5859. [CrossRef]

67. Perou, C.M.; Sorlie, T.; Eisen, M.B.; van de Rijn, M.; Jeffrey, S.S.; Rees, C.A.; Pollack, J.R.; Ross, D.T.; Johnsen, H.; Akslen, L.A.; et al. Molecular portraits of human breast tumours. Nature 2000, 406, 747-752. [CrossRef]

68. Curtis, C.; Shah, S.P.; Chin, S.F.; Turashvili, G.; Rueda, O.M.; Dunning, M.J.; Speed, D.; Lynch, A.G.; Samarajiwa, S.; Yuan, Y.; et al. The genomic and transcriptomic architecture of 2,000 breast tumours reveals novel subgroups. Nature 2012, 486, 346-352. [CrossRef]

69. Blasiak, J.; Pawlowska, E.; Chojnacki, J.; Szczepanska, J.; Fila, M.; Chojnacki, C. Vitamin D in Triple-Negative and BRCA1-Deficient Breast Cancer-Implications for Pathogenesis and Therapy. Int. J. Mol. Sci. 2020, 21, 3670. [CrossRef]

70. Welsh, J. Function of the vitamin D endocrine system in mammary gland and breast cancer. Mol. Cell. Endocrinol. 2017, 453, 88-95. [CrossRef]

71. Berger, U.; Wilson, P.; McClelland, R.A.; Colston, K.; Haussler, M.R.; Pike, J.W.; Coombes, R.C. Immunocytochemical detection of 1,25-dihydroxyvitamin D receptors in normal human tissues. J. Clin. Endocrinol. Metab. 1988, 67, 607-613. [CrossRef] [PubMed]

72. Pendas-Franco, N.; Gonzalez-Sancho, J.M.; Suarez, Y.; Aguilera, O.; Steinmeyer, A.; Gamallo, C.; Berciano, M.T.; Lafarga, M.; Munoz, A. Vitamin D regulates the phenotype of human breast cancer cells. Differentiation 2007, 75, 193-207. [CrossRef] [PubMed]

73. Lopes, N.; Sousa, B.; Martins, D.; Gomes, M.; Vieira, D.; Veronese, L.A.; Milanezi, F.; Paredes, J.; Costa, J.L.; Schmitt, F. Alterations in Vitamin D signalling and metabolic pathways in breast cancer progression: A study of VDR, CYP27B1 and CYP24A1 expression in benign and malignant breast lesions. BMC Cancer 2010, 10, 483. [CrossRef] 
74. Al-Azhri, J.; Zhang, Y.; Bshara, W.; Zirpoli, G.; McCann, S.E.; Khoury, T.; Morrison, C.D.; Edge, S.B.; Ambrosone, C.B.; Yao, S. Tumor Expression of Vitamin D Receptor and Breast Cancer Histopathological Characteristics and Prognosis. Clin. Cancer Res. 2017, 23, 97-103. [CrossRef]

75. Gocek, E.; Studzinski, G.P. Vitamin D and differentiation in cancer. Crit. Rev. Clin. Lab. Sci. 2009, 46, $190-209$. [CrossRef] [PubMed]

76. Narvaez, C.J.; Matthews, D.; LaPorta, E.; Simmons, K.M.; Beaudin, S.; Welsh, J. The impact of vitamin D in breast cancer: Genomics, pathways, metabolism. Front. Physiol. 2014, 5, 213. [CrossRef]

77. Welsh, J. Vitamin D and breast cancer: Past and present. J. Steroid Biochem. Mol. Biol. 2018, 177, 15-20. [CrossRef]

78. Lopes, N.; Carvalho, J.; Duraes, C.; Sousa, B.; Gomes, M.; Costa, J.L.; Oliveira, C.; Paredes, J.; Schmitt, F. 1Alpha,25-dihydroxyvitamin D3 induces de novo E-cadherin expression in triple-negative breast cancer cells by CDH1-promoter demethylation. Anticancer Res. 2012, 32, 249-257.

79. Gonzalez-Sancho, J.M.; Alvarez-Dolado, M.; Munoz, A. 1,25-Dihydroxyvitamin D3 inhibits tenascin-C expression in mammary epithelial cells. FEBS Lett. 1998, 426, 225-228. [CrossRef]

80. Koli, K.; Keski-Oja, J. 1alpha,25-dihydroxyvitamin D3 and its analogues down-regulate cell invasion-associated proteases in cultured malignant cells. Cell Growth Differ. 2000, 11, 221-229.

81. Sundaram, S.; Beckman, M.J.; Bajwa, A.; Wei, J.; Smith, K.M.; Posner, G.H.; Gewirtz, D.A. QW-1624F2-2, a synthetic analogue of 1,25-dihydroxyvitamin D3, enhances the response to other deltanoids and suppresses the invasiveness of human metastatic breast tumor cells. Mol. Cancer Ther. 2006, 5, 2806-2814. [CrossRef] [PubMed]

82. LaPorta, E.; Welsh, J. Modeling vitamin D actions in triple negative/basal-like breast cancer. J. Steroid Biochem. Mol. Biol. 2014, 144, 65-73. [CrossRef] [PubMed]

83. Wilmanski, T.; Barnard, A.; Parikh, M.R.; Kirshner, J.; Buhman, K.; Burgess, J.; Teegarden, D. 1alpha,25-Dihydroxyvitamin D Inhibits the Metastatic Capability of MCF10CA1a and MDA-MB-231 Cells in an In Vitro Model of Breast to Bone Metastasis. Nutr. Cancer 2016, 68, 1202-1209. [CrossRef] [PubMed]

84. Hansen, C.M.; Frandsen, T.L.; Brunner, N.; Binderup, L. 1 alpha,25-Dihydroxyvitamin D3 inhibits the invasive potential of human breast cancer cells in vitro. Clin. Exp. Metastasis 1994, 12, 195-202. [CrossRef] [PubMed]

85. Vanoirbeek, E.; Eelen, G.; Verlinden, L.; Carmeliet, G.; Mathieu, C.; Bouillon, R.; O'Connor, R.; Xiao, G.; Verstuyf, A. PDLIM2 expression is driven by vitamin $\mathrm{D}$ and is involved in the pro-adhesion, and anti-migration and -invasion activity of vitamin D. Oncogene 2014, 33, 1904-1911. [CrossRef] [PubMed]

86. Williams, J.D.; Aggarwal, A.; Swami, S.; Krishnan, A.V.; Ji, L.; Albertelli, M.A.; Feldman, B.J. Tumor Autonomous Effects of Vitamin D Deficiency Promote Breast Cancer Metastasis. Endocrinology 2016, 157, 1341-1347. [CrossRef]

87. Arensman, M.D.; Nguyen, P.; Kershaw, K.M.; Lay, A.R.; Ostertag-Hill, C.A.; Sherman, M.H.; Downes, M.; Liddle, C.; Evans, R.M.; Dawson, D.W. Calcipotriol Targets LRP6 to Inhibit Wnt Signaling in Pancreatic Cancer. Mol. Cancer Res. 2015, 13, 1509-1519. [CrossRef]

88. Xu, S.; Zhang, Z.H.; Fu, L.; Song, J.; Xie, D.D.; Yu, D.X.; Xu, D.X.; Sun, G.P. Calcitriol inhibits migration and invasion of renal cell carcinoma cells by suppressing Smad2/3-, STAT3- and beta-catenin-mediated epithelial-mesenchymal transition. Cancer Sci. 2020, 111, 59-71. [CrossRef]

89. Palmer, H.G.; Anjos-Afonso, F.; Carmeliet, G.; Takeda, H.; Watt, F.M. The vitamin D receptor is a Wnt effector that controls hair follicle differentiation and specifies tumor type in adult epidermis. PLoS ONE 2008, 3, e1483. [CrossRef]

90. Jiang, Y.J.; Teichert, A.E.; Fong, F.; Oda, Y.; Bikle, D.D. 1alpha,25(OH)2-dihydroxyvitamin D3/VDR protects the skin from UVB-induced tumor formation by interacting with the beta-catenin pathway. J. Steroid Biochem. Mol. Biol. 2013, 136, 229-232. [CrossRef]

91. Tapia, C.; Suares, A.; De Genaro, P.; Gonzalez-Pardo, V. In vitro studies revealed a downregulation of Wnt/beta-catenin cascade by active vitamin D and TX 527 analog in a Kaposi's sarcoma cellular model. Toxicol. In Vitro 2020, 63, 104748. [CrossRef] [PubMed]

92. Chiang, K.C.; Kuo, S.F.; Chen, C.H.; Ng, S.; Lin, S.F.; Yeh, C.N.; Chen, L.W.; Takano, M.; Chen, T.C.; Juang, H.H.; et al. MART-10, the vitamin D analog, is a potent drug to inhibit anaplastic thyroid cancer cell metastatic potential. Cancer Lett. 2015, 369, 76-85. [CrossRef] [PubMed] 
93. Hou, Y.F.; Gao, S.H.; Wang, P.; Zhang, H.M.; Liu, L.Z.; Ye, M.X.; Zhou, G.M.; Zhang, Z.L.; Li, B.Y. 1alpha,25(OH)(2)D(3) Suppresses the Migration of Ovarian Cancer SKOV-3 Cells through the Inhibition of Epithelial-Mesenchymal Transition. Int. J. Mol. Sci. 2016, 17, 1285. [CrossRef]

94. Jiang, F.; Yang, Y.; Xue, L.; Li, B.; Zhang, Z. 1alpha,25-dihydroxyvitamin D3 Attenuates TGF-beta-Induced Pro-Fibrotic Effects in Human Lung Epithelial Cells through Inhibition of Epithelial-Mesenchymal Transition. Nutrients 2017, 9, 980. [CrossRef] [PubMed]

95. Lee, E.; Jeon, S.H.; Yi, J.Y.; Jin, Y.J.; Son, Y.S. Calcipotriol inhibits autocrine phosphorylation of EGF receptor in a calcium-dependent manner, a possible mechanism for its inhibition of cell proliferation and stimulation of cell differentiation. Biochem. Biophys. Res. Commun. 2001, 284, 419-425. [CrossRef] [PubMed]

96. Cordero, J.B.; Cozzolino, M.; Lu, Y.; Vidal, M.; Slatopolsky, E.; Stahl, P.D.; Barbieri, M.A.; Dusso, A. 1,25-Dihydroxyvitamin $\mathrm{D}$ down-regulates cell membrane growth- and nuclear growth-promoting signals by the epidermal growth factor receptor. J. Biol. Chem. 2002, 277, 38965-38971. [CrossRef]

97. Boisseau-Garsaud, A.M.; Donatien, P.; Margerin, C.; Taieb, A. EGF receptor expression and growth of psoriatic and normal human keratinocytes are modulated by $1.25(\mathrm{OH}) 2$-vitamin D3 ex vivo. Arch. Dermatol. Res. 1996, 288, 453-457. [CrossRef]

98. Kulling, P.M.; Olson, K.C.; Olson, T.L.; Feith, D.J.; Loughran, T.P., Jr. Vitamin D in hematological disorders and malignancies. Eur. J. Haematol. 2017, 98, 187-197. [CrossRef]

99. Tanaka, H.; Abe, E.; Miyaura, C.; Shiina, Y.; Suda, T. 1 alpha,25-dihydroxyvitamin D3 induces differentiation of human promyelocytic leukemia cells (HL-60) into monocyte-macrophages, but not into granulocytes. Biochem. Biophys. Res. Commun. 1983, 117, 86-92. [CrossRef]

100. Koeffler, H.P.; Amatruda, T.; Ikekawa, N.; Kobayashi, Y.; DeLuca, H.F. Induction of macrophage differentiation of human normal and leukemic myeloid stem cells by 1,25-dihydroxyvitamin D3 and its fluorinated analogues. Cancer Res. 1984, 44, 5624-5628.

101. Liu, M.; Lee, M.H.; Cohen, M.; Bommakanti, M.; Freedman, L.P. Transcriptional activation of the Cdk inhibitor p21 by vitamin D3 leads to the induced differentiation of the myelomonocytic cell line U937. Genes Dev. 1996, 10, 142-153. [CrossRef] [PubMed]

102. Ji, Y.; Studzinski, G.P. Retinoblastoma protein and CCAAT/enhancer-binding protein beta are required for 1,25-dihydroxyvitamin D3-induced monocytic differentiation of HL60 cells. Cancer Res. 2004, 64, 370-377. [CrossRef] [PubMed]

103. Marchwicka, A.; Marcinkowska, E. Regulation of Expression of CEBP Genes by Variably Expressed Vitamin D Receptor and Retinoic Acid Receptor alpha in Human Acute Myeloid Leukemia Cell Lines. Int. J. Mol. Sci. 2018, 19, 1918. [CrossRef] [PubMed]

104. Hmama, Z.; Nandan, D.; Sly, L.; Knutson, K.L.; Herrera-Velit, P.; Reiner, N.E. 1alpha,25-dihydroxyvitamin $\mathrm{D}$ (3)-induced myeloid cell differentiation is regulated by a vitamin D receptor-phosphatidylinositol 3-kinase signaling complex. J. Exp. Med. 1999, 190, 1583-1594. [CrossRef] [PubMed]

105. Studzinski, G.P.; Wang, X.; Ji, Y.; Wang, Q.; Zhang, Y.; Kutner, A.; Harrison, J.S. The rationale for deltanoids in therapy for myeloid leukemia: Role of KSR-MAPK-C/EBP pathway. J. Steroid Biochem. Mol. Biol. 2005, 97, 47-55. [CrossRef]

106. Cao, H.; Xu, Y.; de Necochea-Campion, R.; Baylink, D.J.; Payne, K.J.; Tang, X.; Ratanatharathorn, C.; Ji, Y.; Mirshahidi, S.; Chen, C.S. Application of vitamin D and vitamin D analogs in acute myelogenous leukemia. Exp. Hematol. 2017, 50, 1-12. [CrossRef]

107. Muto, A.; Kizaki, M.; Yamato, K.; Kawai, Y.; Kamata-Matsushita, M.; Ueno, H.; Ohguchi, M.; Nishihara, T.; Koeffler, H.P.; Ikeda, Y. 1,25-Dihydroxyvitamin D3 induces differentiation of a retinoic acid-resistant acute promyelocytic leukemia cell line (UF-1) associated with expression of p21(WAF1/CIP1) and p27(KIP1). Blood 1999, 93, 2225-2233. [CrossRef]

108. Hickish, T.; Cunningham, D.; Colston, K.; Millar, B.C.; Sandle, J.; Mackay, A.G.; Soukop, M.; Sloane, J. The effect of 1,25-dihydroxyvitamin D3 on lymphoma cell lines and expression of vitamin D receptor in lymphoma. Br. J. Cancer 1993, 68, 668-672. [CrossRef]

109. Ohlund, D.; Elyada, E.; Tuveson, D. Fibroblast heterogeneity in the cancer wound. J. Exp. Med. 2014, 211, 1503-1523. [CrossRef]

110. Chen, X.; Song, E. Turning foes to friends: Targeting cancer-associated fibroblasts. Nat. Rev. Drug Discov. 2019, 18, 99-115. [CrossRef] 
111. Augsten, M. Cancer-associated fibroblasts as another polarized cell type of the tumor microenvironment. Front. Oncol. 2014, 4, 62. [CrossRef] [PubMed]

112. Ozdemir, B.C.; Pentcheva-Hoang, T.; Carstens, J.L.; Zheng, X.; Wu, C.C.; Simpson, T.R.; Laklai, H.; Sugimoto, H.; Kahlert, C.; Novitskiy, S.V.; et al. Depletion of carcinoma-associated fibroblasts and fibrosis induces immunosuppression and accelerates pancreas cancer with reduced survival. Cancer Cell 2014, 25, 719-734. [CrossRef] [PubMed]

113. Rhim, A.D.; Oberstein, P.E.; Thomas, D.H.; Mirek, E.T.; Palermo, C.F.; Sastra, S.A.; Dekleva, E.N.; Saunders, T.; Becerra, C.P.; Tattersall, I.W.; et al. Stromal elements act to restrain, rather than support, pancreatic ductal adenocarcinoma. Cancer Cell 2014, 25, 735-747. [CrossRef] [PubMed]

114. Sherman, M.H.; Yu, R.T.; Engle, D.D.; Ding, N.; Atkins, A.R.; Tiriac, H.; Collisson, E.A.; Connor, F.; Van Dyke, T.; Kozlov, S.; et al. Vitamin D receptor-mediated stromal reprogramming suppresses pancreatitis and enhances pancreatic cancer therapy. Cell 2014, 159, 80-93. [CrossRef]

115. Ding, N.; Yu, R.T.; Subramaniam, N.; Sherman, M.H.; Wilson, C.; Rao, R.; Leblanc, M.; Coulter, S.; He, M.; Scott, C.; et al. A vitamin D receptor/SMAD genomic circuit gates hepatic fibrotic response. Cell 2013, 153, 601-613. [CrossRef]

116. Duran, A.; Hernandez, E.D.; Reina-Campos, M.; Castilla, E.A.; Subramaniam, S.; Raghunandan, S.; Roberts, L.R.; Kisseleva, T.; Karin, M.; Diaz-Meco, M.T.; et al. p62/SQSTM1 by Binding to Vitamin D Receptor Inhibits Hepatic Stellate Cell Activity, Fibrosis, and Liver Cancer. Cancer Cell 2016, 30, 595-609. [CrossRef]

117. Campos, L.T.; Brentani, H.; Roela, R.A.; Katayama, M.L.; Lima, L.; Rolim, C.F.; Milani, C.; Folgueira, M.A.; Brentani, M.M. Differences in transcriptional effects of 1alpha,25 dihydroxyvitamin D3 on fibroblasts associated to breast carcinomas and from paired normal breast tissues. J. Steroid Biochem. Mol. Biol. 2013, 133, 12-24. [CrossRef]

118. Ferrer-Mayorga, G.; Gomez-Lopez, G.; Barbachano, A.; Fernandez-Barral, A.; Pena, C.; Pisano, D.G.; Cantero, R.; Rojo, F.; Munoz, A.; Larriba, M.J. Vitamin D receptor expression and associated gene signature in tumour stromal fibroblasts predict clinical outcome in colorectal cancer. Gut 2017, 66, 1449-1462. [CrossRef]

119. Kong, F.; Li, L.; Wang, G.; Deng, X.; Li, Z.; Kong, X. VDR signaling inhibits cancer-associated-fibroblasts' release of exosomal miR-10a-5p and limits their supportive effects on pancreatic cancer cells. Gut 2019, 68, 950-951. [CrossRef]

120. Niell, N.; Larriba, M.J.; Ferrer-Mayorga, G.; Sanchez-Perez, I.; Cantero, R.; Real, F.X.; Del Peso, L.; Munoz, A.; Gonzalez-Sancho, J.M. The human PKP2/plakophilin-2 gene is induced by Wnt/beta-catenin in normal and colon cancer-associated fibroblasts. Int. J. Cancer 2018, 142, 792-804. [CrossRef]

121. Ferrer-Mayorga, G.; Niell, N.; Cantero, R.; Gonzalez-Sancho, J.M.; Del Peso, L.; Munoz, A.; Larriba, M.J. Vitamin D and Wnt3A have additive and partially overlapping modulatory effects on gene expression and phenotype in human colon fibroblasts. Sci. Rep. 2019, 9, 8085. [CrossRef] [PubMed]

122. Wu, X.; Hu, W.; Lu, L.; Zhao, Y.; Zhou, Y.; Xiao, Z.; Zhang, L.; Zhang, H.; Li, X.; Li, W.; et al. Repurposing vitamin $\mathrm{D}$ for treatment of human malignancies via targeting tumor microenvironment. Acta Pharm. Sin. B 2019, 9, 203-219. [CrossRef] [PubMed]

123. Schwitalla, S.; Fingerle, A.A.; Cammareri, P.; Nebelsiek, T.; Goktuna, S.I.; Ziegler, P.K.; Canli, O.; Heijmans, J.; Huels, D.J.; Moreaux, G.; et al. Intestinal tumorigenesis initiated by dedifferentiation and acquisition of stem-cell-like properties. Cell 2013, 152, 25-38. [CrossRef]

124. Plaks, V.; Kong, N.; Werb, Z. The cancer stem cell niche: How essential is the niche in regulating stemness of tumor cells? Cell Stem Cell 2015, 16, 225-238. [CrossRef]

125. Murata, K.; Jadhav, U.; Madha, S.; van Es, J.; Dean, J.; Cavazza, A.; Wucherpfennig, K.; Michor, F.; Clevers, H.; Shivdasani, R.A. Ascl2-Dependent Cell Dedifferentiation Drives Regeneration of Ablated Intestinal Stem Cells. Cell Stem Cell 2020, 26, 377-390.e376. [CrossRef] [PubMed]

126. Chaffer, C.L.; Brueckmann, I.; Scheel, C.; Kaestli, A.J.; Wiggins, P.A.; Rodrigues, L.O.; Brooks, M.; Reinhardt, F.; $\mathrm{Su}$, Y.; Polyak, K.; et al. Normal and neoplastic nonstem cells can spontaneously convert to a stem-like state. Proc. Natl. Acad. Sci. USA 2011, 108, 7950-7955. [CrossRef]

127. Jeong, Y.; Swami, S.; Krishnan, A.V.; Williams, J.D.; Martin, S.; Horst, R.L.; Albertelli, M.A.; Feldman, B.J.; Feldman, D.; Diehn, M. Inhibition of Mouse Breast Tumor-Initiating Cells by Calcitriol and Dietary Vitamin D. Mol. Cancer Ther. 2015, 14, 1951-1961. [CrossRef] 
128. So, J.Y.; Wahler, J.; Das Gupta, S.; Salerno, D.M.; Maehr, H.; Uskokovic, M.; Suh, N. HES1-mediated inhibition of Notch1 signaling by a Gemini vitamin D analog leads to decreased CD44(+)/CD24(-/low) tumor-initiating subpopulation in basal-like breast cancer. J. Steroid Biochem. Mol. Biol. 2015, 148, 111-121. [CrossRef]

129. Wahler, J.; So, J.Y.; Cheng, L.C.; Maehr, H.; Uskokovic, M.; Suh, N. Vitamin D compounds reduce mammosphere formation and decrease expression of putative stem cell markers in breast cancer. J. Steroid Biochem. Mol. Biol. 2015, 148, 148-155. [CrossRef]

130. Shan, N.L.; Wahler, J.; Lee, H.J.; Bak, M.J.; Gupta, S.D.; Maehr, H.; Suh, N. Vitamin D compounds inhibit cancer stem-like cells and induce differentiation in triple negative breast cancer. J. Steroid Biochem. Mol. Biol. 2017, 173, 122-129. [CrossRef]

131. Srivastava, A.K.; Rizvi, A.; Cui, T.; Han, C.; Banerjee, A.; Naseem, I.; Zheng, Y.; Wani, A.A.; Wang, Q.E. Depleting ovarian cancer stem cells with calcitriol. Oncotarget 2018, 9, 14481-14491. [CrossRef] [PubMed]

132. Ji, M.; Liu, L.; Hou, Y.; Li, B. 1alpha,25Dihydroxyvitamin D3 restrains stem celllike properties of ovarian cancer cells by enhancing vitamin D receptor and suppressing CD44. Oncol. Rep. 2019, 41, 3393-3403. [CrossRef] [PubMed]

133. Jensen, M.B.; Jorgensen, A.; Nielsen, J.E.; Steinmeyer, A.; Leffers, H.; Juul, A.; De Meyts, E.R. Vitamin D metabolism and effects on pluripotency genes and cell differentiation in testicular germ cell tumors in vitro and in vivo. Neoplasia 2012, 14, 952-963. [CrossRef] [PubMed]

134. Fernandez-Barral, A.; Costales-Carrera, A.; Buira, S.P.; Jung, P.; Ferrer-Mayorga, G.; Larriba, M.J.; Bustamante-Madrid, P.; Dominguez, O.; Real, F.X.; Guerra-Pastrian, L.; et al. Vitamin D differentially regulates colon stem cells in patient-derived normal and tumor organoids. FEBS J. 2020, 287, 53-72. [CrossRef]

135. Costales-Carrera, A.; Fernandez-Barral, A.; Bustamante-Madrid, P.; Dominguez, O.; Guerra-Pastrian, L.; Cantero, R.; del Peso, L.; Burgos, A.; Barbachano, A.; Muñoz, A. Comparative study of organoids from patient-derived normal and tumor colon and rectal tissue. Cancers 2020, 12, 2302. [CrossRef] [PubMed]

136. Peregrina, K.; Houston, M.; Daroqui, C.; Dhima, E.; Sellers, R.S.; Augenlicht, L.H. Vitamin D is a determinant of mouse intestinal Lgr5 stem cell functions. Carcinogenesis 2015, 36, 25-31. [CrossRef]

137. Augenlicht, L.H. Environmental Impact on Intestinal Stem Cell Functions in Mucosal Homeostasis and Tumorigenesis. J. Cell. Biochem. 2017, 118, 943-952. [CrossRef]

138. Li, W.; Zimmerman, S.E.; Peregrina, K.; Houston, M.; Mayoral, J.; Zhang, J.; Maqbool, S.; Zhang, Z.; Cai, Y.; Ye, K.; et al. The nutritional environment determines which and how intestinal stem cells contribute to homeostasis and tumorigenesis. Carcinogenesis 2019, 40, 937-946. [CrossRef]

139. Wang, L.Q.; Yu, P.; Li, B.; Guo, Y.H.; Liang, Z.R.; Zheng, L.L.; Yang, J.H.; Xu, H.; Liu, S.; Zheng, L.S.; et al. miR-372 and miR-373 enhance the stemness of colorectal cancer cells by repressing differentiation signaling pathways. Mol. Oncol. 2018, 12, 1949-1964. [CrossRef]

140. Paubelle, E.; Zylbersztejn, F.; Maciel, T.T.; Carvalho, C.; Mupo, A.; Cheok, M.; Lieben, L.; Sujobert, P.; Decroocq, J.; Yokoyama, A.; et al. Vitamin D Receptor Controls Cell Stemness in Acute Myeloid Leukemia and in Normal Bone Marrow. Cell Rep. 2020, 30, 739-754.e734. [CrossRef]

(C) 2020 by the authors. Licensee MDPI, Basel, Switzerland. This article is an open access article distributed under the terms and conditions of the Creative Commons Attribution (CC BY) license (http://creativecommons.org/licenses/by/4.0/). 